\title{
Episodes of Fluctuating Oil Prices Through the New-Normal Era: The Historical Perspective (1946-2020)
}

\author{
Millicent Adanne Eze* Reza Kouhy \\ School of Business, Law and Social Sciences, Abertay University, Scotland, United Kingdom \\ * E-mail of the corresponding author: ezemillicent@gmail.com; 1404750@abertay.ac.uk \\ ORCID Identifier: https://orcid.org/0000-0002-2951-4027
}

\begin{abstract}
Crude oil as a principal energy source is one of the most dynamically transacted commodities, and changes in oil price have been a constant phenomenon over the years. The uncertainty associated with fluctuations in oil price affects global economic stability. However, this paper centers on historical events and trends of fluctuating oil prices at different periods, including the recent new-normal era of the COVID-19 pandemic. It captured all the detailed oil price shocks' events at various intervals, from 1946-2020 and the possible factors responsible for the constant changes in the global oil prices. An economic model is proposed to close the revenue gaps in these highly oil-dependent nations, given that the "oil age" is gradually fizzling out.
\end{abstract}

Keywords: Episodes, Fluctuating Oil Prices, Oil-exporting nations, Covid-19 Pandemic, Declining Oil Revenue, Economic Model

DOI: $10.7176 / \mathrm{HRL} / 53-03$

Publication date: April $30^{\text {th }} 2021$

\subsection{Introduction}

Oil is a form of power, while oil reserves possession is a source of geopolitical power ${ }^{1}$. Crude oil is indeed one of the most dynamically transacted commodities worldwide. Changes in oil price remain a constant phenomenon since February 1946, when the oil price was as low as $\$ 1.17$ per barrel to July 2008 when oil price peaked at $\$ 145.31$ per barrel. Presently, as of the $6^{\text {th }}$ of February, 2021, the oil price is trading at an average of $\$ 56.81$ per barrel (WTI) and \$59.34 per barrel (Brent Crude) (Oilprice.com, 2021), lower than the oil price outlined by the oil-exporting nations to balance their budgets. Most of these oil-exporting countries have been experiencing uncommon setback due to the decline in oil price, leading to the collapse of the global oil market and the drastic contraction in the global economic activities due to the unanticipated COVID-19 pandemic that has ravaged the entire world, hence, the new normal. As a result, in April, 2020, oil price tends towards negative for the very first time in the history of oil price shocks (IEA, 2020).

This paper, however, examines the episodes, trends, interaction, reaction and impact of fluctuating oil prices on both oil-exporting and oil-importing economies, through the new-normal era, from 1945-2020. It has contributed immensely in details to the ongoing debate relating to oil price fluctuations and the macroeconomy. After World War II, oil controlled the world's energy market ${ }^{2}$ as the importance of oil remains incontestable in the global economy. It is no doubt that oil revenue plays a significant role in economies of both importing and exporting countries and with diverse effects on different economies (The Assam Tribune, 2016; Rahman, 2004).

Unlike the previous oil shocks, the present oil price series, which began since the year 2014, is because of a combination of many factors; demand factor, supply factor or both and the unanticipated Covid-19 pandemic which has ravaged the entire globe as it has affected every aspect of human life. A slight change in the price of crude has a direct effect on the economic performance of both oil-exporting and oil-importing economies. Hence, the assessment of the trends in oil prices in the global economy becomes imperative (Al-Hamad and Verleger, 2016). Klevnas et al. (2015) also posit that low-carbon policy ambition can reduce oil prices by more than 50\% in the long term. However, there is an urgent need to reduce $\mathrm{CO} 2$ emissions in the environment while most economies are presently moving towards the expansion of international markets for the trading of green energy goods and services (OECD, 2015). Although Nachtigall and Rübbelke (2013) and Sinn (2012) maintained that empirically, there had not been any evidence to prove that the fall in oil prices in recent time was hinged on the green paradox ${ }^{3}$.

Reliance on oil has caused the world oil shock and the primary source of macroeconomic fluctuations that have well possessed a significant impact on both macroeconomic policy and economic activities in most oildependent nations. From the global perspectives, the decline in oil revenue might affect economic performance relating to its impact on government spending, money supply, inflation, real exchange rate and import (Emani

\footnotetext{
${ }^{1}$ Oil is a form of power and the most dynamically transacted commodities in the world today. See Lin, 2011.

${ }^{2}$ After the Second World War, oil controlled the world's energy market. See Rahman, 2004.

${ }^{3}$ Sinn first proposed 'Green Paradox' in 2008, which entails a pragmatic approach of controlling the supply of non-renewable energy rather than its demand.
} 
and Adibpour 2012; Strum et al. 2009). For the private sectors, lower oil price led to less profit in oil exploration and extractive activities ${ }^{1}$.

The impact of the global oil price changes on the world economy cannot be over-emphasised; as such, an in-depth understanding of the oil price trends in the global economy becomes very necessary. This understanding would aid policymakers to create strategic responses, which would assist in mitigating those impacts. Many researchers have made meaningful contributions to the debate on oil price fluctuations and the effects on the global economy. Some of these studies are those of (Nzimade and Msomis, 2016; Baumeister and Kilian, 2016; Balli et al., 2016; Al-Hamad and Verleger, 2016; Timilsina 2014; Blanchard and Riggi 2013; Morana 2013; Kilian 2009; Jimenez-Rodriguez and Sanchez 2005; Barsky and Kilian 2004; Mork 1989; and Hamilton 2011, 2009, 2008, 2005, 1996, 1983).

However, the emphases of the above related studies, revolve around the consequences of an increase in oil price on the world economy. This study instead, centres on the effects of decreasing oil prices, which in turn metamorphose into decreasing oil revenues of most of the oil-dependent economies. Although, decreasing oil price is supposed to be favourable to oil-importers by increasing their profit margin and also help in increasing their economic activities. Yet, the reverse was the case during the current oil price shock that began since 2014 through the year 2020 as all the economic activities of both oil-exporters, oil-importers and the entire globe were crippled due to the unanticipated COVID-19 pandemic which transitioned the globe into the new-normal era.

Other related studies focused on the impact of oil price fluctuation on developed oil-importing nations such as Baumeister and Kilian, (2016); Taghizadeh-Hesari and Yoshino (2015); Yoshino and Taghizadeh-Hesari, (2014). Qianqian, (2011) analysed the impact of oil price fluctuation on the Chinese economy. The paper focused mainly on the impact of increasing oil price on the economy concerned. Some other more closely related historical studies are Monaldi, (2015) who carried out an examination of the effect of declining oil price but for one economy, i.e. for the Venezuelan macroeconomy. Husain et al., (2015) analysed the global implications of lower oil prices for both oil-importing and oil-exporting nations but the period of study was too small, from 2014-2015; it did not capture the new-normal era due to the covid-19 pandemic. Howevever, this study is different, given that the period of coverage is large, from 1946 to 2020. Similarly, Holden, (2013) carried out a historical review on avoiding the resource curse but the study examined only the Norwegian economy. Also, all the series of Hamilton's historical sudies on oil price fluctuations and the macroeconomy are mainly on the United States of America which is developed and oil importing nation. Nevertheless, Stevens, (2009) carried out a historical review of declining oil revenues in the GCC States but the period captured in his study was mainly during the global financial crisis of 2007 to 2008.

This study however, differ significantly from all these other related studies as it dealt with effect of fluctuating oil prices on both oil-exporting and oil-importing nations amidst the COVID-19 pandemic. The period of coverage of this study is also very large, relative to other similar studies; from 1946 to 2020 (74 years) and it captured all the events relating to fluctuating oil prices at different intervals. However, to the best of our knowledge, there is no related study that captured detailed episodes of crude oil fluctuations for such number of years. More so, an economic model has been proposed to close the revenue gaps in most of the highly oildependent nations, given that the "oil age" is gradually fizzling out as more nations are going green which is revealed to be environmentally friendly.

\subsection{The History and Trends of Changes in Oil Price}

Historically, there have been drastic changes in the price of oil since February 1946 when the oil price was as low as $\$ 1.17$ per barrel to July 2008 when oil price reached its peak of $\$ 145.31$ per barrel. As at November, 1998 , oil price was $\$ 17.82$ per barrel; $\$ 20.60$ per barrel in March 2020 . Presently, oil price as at the $5^{\text {th }}$ of February 2021 was traded at $\$ 56.85$ per barrel $^{2}$. The changes in oil price in the whole series from 1946 to present are as shown in the figure below:

\footnotetext{
${ }^{1}$ Lower oil price led to less profit in oil exploration and extractive activities; see Obstfeld et al., 2016.

${ }^{2}$ The price of oil as at the 5th of February 2021 traded at \$56.85 per barrel. See Macrotrends, 2010-2021.
} 
Figure 2.1 70-Year Historical Chart of WTI Crude Oil Prices (1946-2020)

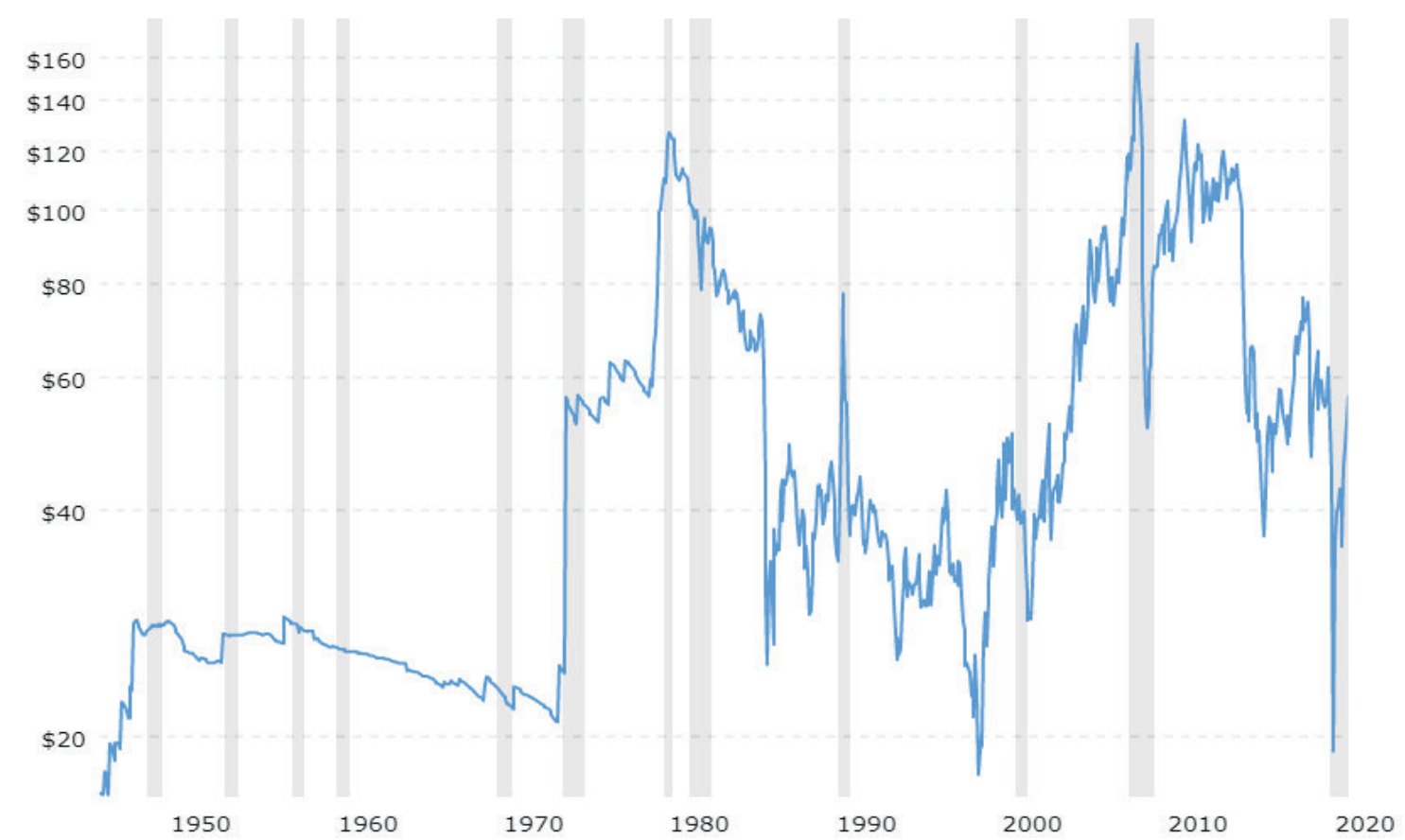

Source: Macrotrends, (2021): Crude Oil Prices - 70 Year Historical Chart

The crude oil trends and path from 1946 through 2020 is highly consistent with those of Roberts, (2018). There is persistent decline in oil price since June 2014 from the high price of \$115 per barrel to less than \$35 per barrel as at February ending, 2016. More so, the Organization of Petroleum Exporting Countries (OPEC) has not been able to reduce oil production even after its meeting to do so, on the $5^{\text {th }}$ of March, 2020 further led to the decline of oil price to $\$ 31.1$ per barrel. Oil price further declined to $\$ 11.57$ per barrel by the $21^{\text {st }}$ of April, 2020 due to the impact of the COVID-19 pandemic and this is one of the many significant macroeconomic developments globally in recent time (OECD, 2020; Taghizadeh-Hesary 2020). The sharp decrease in the price of oil is akin in magnitude with those of early 1981 to 1986 which was mainly supply-driven and the 2008 to 2009 decline which was due to a decrease in demand, triggered by the global financial crisis of the period. The recent years' drop seems to be the mixture of both supply and demand factors (Rogoff, 2016).

There was a loss of $\$ 13.37$ per barrel, which is about 26.51\% since April 2015 as the price of oil declined from $\$ 50.44$ to $\$ 37.07$ per barrel on the $7^{\text {th }}$ of April 2016 (Trading Economics, 2016). There was a severe regulation of the United States price of oil through the control of prices or production in almost the whole of the twentieth century (Williams, 2011). The US recessions since World War II usually emanate from the drastic increase in the price of oil (Hamilton 1983). It still does not indicate that the recessions were triggered by the increase in the price of oil. It shows that from 1948 to 1972 that this relationship was statistically substantial and non-spurious. It, therefore, supported the motion that believed that before 1972, some of the USA recessions were highly attributed to the oil price increases of the periods.

Studies, as mentioned earlier, laid more emphasis on oil price increase and did not consider the periods of decline in oil price. IEA Washington DC (2016), Hamilton (2011), Bowen (2011), Williams (2011, 2007, 1999), Barsky and Kilian (2004) gave a well-articulated historical account of the changes in oil price at different periods. The IEA Washington DC (2016) showed the factors that influence the oil markets using charts as well as monthly and quarterly data. The chart indicates that oil crude plays a very significant role in commodity investment. The current prices of work cum investment stocks were regarded as strong determinants of future oil price from 2003 to 2008 due to OPEC's inability to meet up with the high demand because of their low level of production (IEA Washington DC, 2016).

Indications, as expressed above, revealed that the changes in non-OPEC production also affect the oil prices and that the price of oil around the globe move together due to arbitrage ${ }^{1}$. It also reveals that oil prices respond to diverse geopolitical and commercial activities while the increase in oil price and consumption decrease in OECD countries coincides ${ }^{2}$. Oil price impact on the consumption of OECD countries has been higher than that of non-

\footnotetext{
${ }^{1}$ The price of oil around the globe moves together, due to arbitrage, which exists because of market inefficiencies. Arbitrage entails the simultaneous buying and selling of any asset to benefit from the price difference. See IEA Washington DC, 2016.

${ }^{2}$ OECD stands for Organization of Economic Cooperation and Development that consists more of advanced economies, the United States and more of the European countries. See US Energy Information Administration (OECD, 2015).
} 
OECD countries, due to the slower growth while oil price increases as the OECD oil consumption fell drastically from 2006 to 2009 and during the economic downturn (EIA, 2015). However, the studies also center mainly on the impact of increasing oil price on the macroeconomy.

\subsection{The Post World War Period (1946-1971)}

Throughout the Post World War II, there have been irregular increases in the oil price ${ }^{1}$ (Hamilton 1985; 1983). Oil prices have been inconsistent due to the forces of demand and supply in the world's oil market ${ }^{2}$. Both the oil importers and oil exporters find oil prices very critical in dealing with the affairs of the economies as oil serves as a crucial input to oil importers and a good source of revenue generation for the oil exporters. Both are economically dependent on oil, as such, fluctuations in oil price tend to affect both the market sides (Al-Quadsi and Ali 2016). The Texas Railroad Commission was a significant factor in the world oil market at the beginning of the post-war period. In that early post-war period, this commission usually takes advantage of the obstructions in the external supply of oil to produce unexpected random variations in oil prices. The nominal price of oil in this period of Texas Railroad Commission fluctuates to react to specific unique events (Hamilton, 2011; Adelman, 1990).

Until 1974, the United States had been the largest consumer and producer of oil in the world; as there were post-war disruptions by 1947-1948. This gesture led to the abrupt speeding up of country's switch to the era of the automobile. The United States demand for oil increased drastically by about 12 per cent, and their automobile record-keeping also rose 22 per cent. Within these two years, oil price increased by over 80 per cent (Hamilton, 2011). 1948 marked the commencement of the first post-war depression due to the general reduction in the construction spending of residents while the price of oil increased from $\$ 2.50$ per barrel in 1948 to $\$ 3.00$ per barrel in 1957. This price remained stable until $1970^{3}$.

The Korean battle brought about the interruptions in oil supply in 1952-1953. The second post-war recession started within this period because of the rise in oil price by 10 per cent as they lifted the price control in $1953^{4}$. Oil price was static due to the Korean Conflict. The monthly production of the Iranian government of about 19 million barrels was boycotted from the market in 1951's summertime by the world because of Mohammad Mossadegh; the then Prime Minister nationalised the oil industry in Iran. There was an order to reduce the delivery of fuel for the civilian flights by 30 per cent by both the British government and the United States. There was also an established intentional plan to ration gasoline for motor vehicles by the Kansas City and Toledo while Chicago halted 300 public buses. All these led to the above second post-war recessions that frozen the oil price (Hamilton, 2011 and Williams, 2007).

The oil price was affected within 1956-1957 by the Suez Crisis as Gamal Abdel Nasser, the then President of Egypt, nationalised the Suez Canal. After the Second World War, the canal continued to be tactically essential because it served as a channel for the delivery of crude oil. Its application was as the highway of oil that connects Africa and other Asian countries. As of 1955, the shipment of oil products was responsible for the traffic experienced in the canal ${ }^{5}$. In the course of the crisis, the canal was blocked by about 40 boats that hindered daily transportation of millions of barrels through the route.

Hamilton did not stipulate specifically what the effect was on the price of oil at the time though the study was highly in-depth historically as it outlined what happened at each period. Such obstruction in the Suez Canal would, of course, lead to shortages in the supply of oil which will, in turn, bring about the increase in the price of oil which Hamilton (2011) work failed to capture.

Mcmahon (2015) maintained that oil prices were stable within 1958-1971 as the price of oil revolves around an average of $\$ 3.01$ per barrel at that period. However, these prices were just the historical unrestricted market values, and the study did not capture the oil price stimulant in this case. The outcome of the survey is highly consistent with those of Williams, (2011, 1999, and 2007) and Moffat, (2008) who revealed that at that same period, oil prices were highly stable at about $\$ 3.00$ per barrel. Meanwhile, IOGA (2015) maintained that as six more countries joined OPEC, in 1971, oil price control moved to OPEC ${ }^{6}$. The exact oil price movements at the period not outlined.

On the contrary, Hamilton, (2011) in examining this period in his study claimed that there was instead a

\footnotetext{
${ }^{1}$ Throughout the Post World War II period, there have been irregular increases in oil price See Hamilton, (1985; 1983).

${ }^{2}$ The inconsistency in the oil prices is largely due to the forces of demand and supply in the world's oil market. See (Baumeister and Kilian, 2016; Alquist et al. 2013; Dvir and Rogoff 2010).

${ }^{3} 1948$ marked the commencement of the first post-war depression due to the general reduction in the construction spending of residents while the price of oil increased from $\$ 2.50$ per barrel in 1948 to $\$ 3.00$ per barrel in 1957. See (Hamilton, 2011; Reisdorf, 2008; Williams, 1999; Williamson, 1966).

${ }^{4}$ Second post war recession took place from 1952-1953. See Hamilton, 2011.

${ }^{5}$ As at 1955, the shipment of oil products was responsible for the traffic experienced in the Suez Canal, see Hamilton, (2011).

${ }^{6}$ OPEC as a permanent intergovernmental organization was found by five countries in September 1960 in Baghdad, Iraq and it stands for Organization of Petroleum Exporting Countries. As six more countries joined OPEC, in 1971, oil price control moved from the US to OPEC. See (OPEC, 2018; Reisdorf, 2008).
} 
modest increase of about $7 \%$ in oil price as a reaction to the late 1960 's inflationary forces. The shortfall in oil supply due to the strike by the oil deliverers and by the Atomic, Chemical and Oil Workers Union were the major factors responsible for the price increase. The price further rose by $8 \%$ due to the destruction of the TransArabian pipeline in 1970 , leading to the fifth post-war recession ${ }^{1}$. However, the study was not specific as to the exact price movement like the preceded examined studies. The discrepancies relative to the previous studies prevailed on this study's contribution to the body of literature, by reassessing both the past and current oil price history and trends to address it.

\subsection{The Restriction of oil by OPEC: Yom Kippur War (1972-1974)}

After the Post World War Period of1945-1971, then the Yom Kippur War, this entails the restriction of, oil production by OPEC. Organisation of Petroleum Exporting Countries (OPEC) was established in 1960, by only five oil-exporting countries but has now expanded to fourteen member countries. One of their roles is to regulate crude oil production to influence oil prices ${ }^{2}$. Before this period, the group of seven large universal oil firms often referred to as Seven Sisters, or the majors controlled more than half of the world's oil reserves. They conducted their operation effectively through combined ownership of firms, which are in operation in diverse countries. Vertical integration characterised their operations, while both the upstream and downstream operations were under their control as well. Both the vertical and horizontal connections empowered these international oil firms to control most of the oil exports from all the major oil-producing economies thereby minimising the risk of pushing the oil price below their targeted level (Campbell, 2012; Goswami, 2012)

Campbell, (2012) posits that the realisation that oil can be obtained easily through acquisition than by exploration brought about the merging of the Seven Sisters into four. The coming of the independent oil companies who invested in the upstream operations enabled them to have access to crude petroleum outside the Seven Sister's control. In the international market, these Majors enjoyed an oligopolistic market system in the 1950s and 1960s. They maintained an integrated price structure globally, which was above cost price but at the same time, very low to discourage new markets for oil products. These Majors diplomatically handled political disturbances.

There was never any obstruction to the oil reserves in the host economies. Within that 1950 period, the oil price was not fluctuating but somewhat stable (Goswami, 2012). The above assertion is highly consistent with the view of Al-Yousef (1998). It maintained that OPEC had the power to control prices in the oil market around 1973 to 1978 since it had a very high share of the oil market alongside Saudi Arabia as the demand for oil was fluctuating within the period and subsequently reduced in 1975, which was highly responsible for the economic recession at the time. Due to the inelastic supply curve, the price of oil stabilised at $\$ 11.58$ per barrel average and subsequently increased to $\$ 12.7$ per barrel.

After the Yom Kippur War oil crisis in 1973, the dominance of the oil industry shifted to OPEC and other state-owned oil corporations (Goswami 2012). There was a drastic decrease in the total oil production of OPEC because of its restriction of oil exports to some selected countries that they feel are in support of Israel when an attack was laid on Israel by Syria and Egypt in 1973. The global oil output decreased to about $7.5 \%$ while the increase in the production of other countries was not enough to balance the shortage. As a result, the price of oil increased twice in 1974 (Hamilton, 2011).

Contrary, Hammes and Wills (2005); Barsky, and Kilian (2001) argued that the war between the Arabian countries and the Israelites remain inconsequential to explain the OPEC embargo. They observed that both political and economic motivations were instead some of the factors behind such upheaval since the restriction was over without the achievement of those intentions. Hammes and Wills (2005) maintained strongly that economic influence is the most convincing factor in explaining the oil price shock of the period and not the political factors as emphasised by Barsky and Kilian (2001) and Hamilton, (1999). They maintain that the political activities in the Middle East brought about the drastic reduction in oil production, which in turn raised the oil price very high to about $135 \%$ higher, from $\$ 4.31$ to $\$ 10.11$. The drastic increase in oil price had a significant impact on the world economy as a whole. Apart from attributing the high oil increase to political and nationalisation events, Hammes and Wills (2005) were also of the view that OPEC members were an effective cartel, and that is why they were able to implement the drastic oil price increase efficiently at the time. Unlike most other views, Barsky and Kilian (2002) argue that the quadrupling of the oil price has nothing to do with the OPEC embargo. Instead, the oil price increase was just about a half increase while the second half increased before the oil embargo.

This assertion backed up the claim that the oil embargo was pre-empted earlier before the war. The study strongly emphasises that the price increase at this period was demand-driven. In addition to the above arguments, Hamilton was of the view that economic factors alone were not enough as geopolitical factors also

\footnotetext{
${ }^{1}$ The price further rose by $8 \%$ due to the destruction of the Trans-Arabian pipeline in 1970 leading to the fifth post-war recession. See Hamilton, (2011).

${ }^{2}$ OPEC regulates crude oil production to influence oil prices. See (IOGA, 2015; Li, 2010; Reisdorf, 2008).
} 
contributed as well. Hejny and Nielsen (2003) supported that the energy crisis of 1972-74, 1978-1979 and those of the 1990s was mostly due to political disorder in most economies that export oil and because of the high increase in the demand for petroleum.

They emphasise that most top oil producers with a substantial economic stake not behind the oil embargo but rather some of the hostile countries without any oil to export were profoundly in support of the embargo. These studies centred more on mechanisms, rather than the exact price movement at the period.

Nevertheless, (Mcmohan 2015; Alkhathlan, Gately and Javid 2013; Goswami, 2012; Williams 2011, 2007 and 1999; Bowen 2011 and Moffat 2008) were specific in their own studies. They concluded that the oil price change of 1972 to 1974 tripled from $\$ 3.00$ per barrel to about $\$ 12.00$ per barrel ${ }^{1}$. Mcmohan (2015) which study centred around the quadrupling of the oil price from about $\$ 3.00$ per barrel in 1964 to about $\$ 12.21$ per barrel in 1975 only outlined the changes in the price of oil, without attributing the quadrupling of the oil price, to any event. Williams $(2011,2007$, and 1999) further attributed the $400 \%$ increase in the price of oil within the short period of six months' intervals to show and eliminate doubts that the ability to regulate the price of oil had moved from the United States to the OPEC countries. As OPEC drastically reduced production due to the embargo, the price skyrocketed, but the price of oil normalised after the ban.

Alkhathlan, Gately and Javid (2013), Goswani (2012), Pindyck (2001) and Gately (1984) posits that aside from the assertions of blundering actions of some of the OPEC countries during the Yom Kippur War, the unexpected event can further be explained better by two competing theories. The first theory argues that OPEC intentionally restricted production and increased the oil price due to its exploitive power as a cartel ${ }^{2}$. That is, the oil industry was entirely monopolised by OPEC as they quoted the price of oil and as well controlled the amount of oil produced. This view is the most commonly accepted by economists (Gately, 1984).

Pindyck (2001) viewed the period from the theory of exhaustible resources by using a functional wealthmaximisation model. The study attributed OPEC's behaviour of simultaneously cutting production and increasing the price of oil to the exhaustible nature of the petroleum product. The primary emphasis is that competing for oil-producing countries gave much attention to the inevitable depletion of the oil product. It maintains that OPEC inadvertently cut down production and as well as increased prices, which tend towards the monopoly level.

Contrary to the above assertions, most of the OPEC countries at the time still have more than enough oil reserves, and the issue was not the exhaustibility of the petroleum resources. There was crude oil in most of the countries within the period, and as such, very high oil reserves as can be seen from the table created below.

Table 2. 1: FACTS AND FIGURES OF OPEC COUNTRIES

\begin{tabular}{|c|c|c|c|c|c|}
\hline $\mathbf{S} / \mathbf{N}$. & COUNTRIES & $\begin{array}{l}\text { DATE OF OIL } \\
\text { DISCOVERY }\end{array}$ & $\begin{array}{l}\text { DATE } \\
\text { PRODUCTION } \\
\text { STARTED }\end{array}$ & $\begin{array}{l}\text { OPEC } \\
\text { MEMBERSHIP } \\
\text { DATE }\end{array}$ & $\begin{array}{l}\text { PROVEN } \\
\text { CRUDE OIL } \\
\text { RESERVES } \\
\text { (BILLION } \\
\text { BARRELS) }\end{array}$ \\
\hline 1. & Algeria & 1956 & 1958 & 1969 & $12.20(1.0 \%)$ \\
\hline 2. & Angola & 1955 & 1955 & 2007 & $9.52(0.8 \%)$ \\
\hline 3. & Ecuador & 1921 & 1921 & 1973 and 2007 & $8.27(0.7 \%)$ \\
\hline 4. & Indonesia & 1885 & 1885 & 1962 and 2016 & $3.23,(0.3 \%)$ \\
\hline 5. & Iran & 1908 & 1908 & $1960(\mathrm{FM})$ & 158.4. (13.1\%) \\
\hline 6. & Iraq & 1927 & 1927 & $1960(\mathrm{FM})$ & $142.50(11.7 \%)$ \\
\hline 7. & Kuwait & 1938 & 1946 & $1960(\mathrm{FM})$ & $101.50(8.4 \%)$ \\
\hline 8. & Libya & 1959 & 1961 & 1962 (FM) & $48.36(4.0 \%)$ \\
\hline 9. & Nigeria & 1956 & 1956 & 1971 & $37.06(3.1 \%)$ \\
\hline 10. & Qatar & 1935 & 1940 & 1961 & $25.24(2.1 \%)$ \\
\hline 11. & Saudi Arabia & 1938 & 1938 & 1960 (FM) & $266.46(22.0 \%)$ \\
\hline 12. & $\begin{array}{l}\text { United Arab } \\
\text { Emirate }\end{array}$ & 1958 & 1958 & 1967 & $97.80(8.1 \%)$ \\
\hline 13. & Venezuela & 1914 & 1914 & $1960(\mathrm{FM})$ & $300.88(24.8 \%)$ \\
\hline 14. & Gabon & 1931 & 1931 & $\begin{array}{l}1975-1995 \text { and } \\
2016\end{array}$ & $2.00(0.2 \%)$ \\
\hline
\end{tabular}

\section{Source: Developed by the author, adapted from 2016 OPEC Reports}

However, if the crude oil reserves, of these economies, are still as high as depicted on the table presented,

${ }^{1}$ Oil price fluctuation from 1972 to 1974 tripled from $\$ 3.00$ per barrel to about $\$ 12.00$ per barrel. See Mcmohan (2015); Alkhathlan et al., (2013); Goswami, (2012); Williams (2011, 2007 and 1999); Bowen (2011) and Moffat (2008).

${ }^{2}$ The first theory argues that OPEC intentionally restricted production and increased the oil price due to its exploitive power as a cartel. See Gately, (1984). 
meaning that as at the period of the OPEC embargo in the '70s, the oil reserves were much higher. The above scenario counters the exhaustibility claims by the authors mentioned above. It is very evident that economic and political factors, as well as the gains from global oil market derived by the cartel and the underlying market conditions, were designed to benefit OPEC members which led to oil price shock. It was because of the increasing level of demand for oil, which was not able to equate supply and given the fact that the main aim of any business is to maximise profit and to minimise cost. Non-OPEC countries could not produce enough to equate the shortage created in the oil market due to the high cost of production.

OPEC probably utilised the opportunity of the high demand of the petroleum product and the low level of production by non-OPEC members to maximise their profit using the Yom Kippur War; coupled with the fact that the war started due to the attack on Israel by the Arabian countries. The reasons for the attack were not mentioned by any of those studies and as such, politically oriented. Barsky and Kilian (2001) maintained that the oil-producing Arabian countries had discussed and planned the execution of the embargo before the war. They also noted that the most important political objectives purported were not even achieved before the end of the ban. Those intended policy objectives were not outlined in their studies. It was like a predetermined event while the Yom Kippur War serves as a tool for its execution.

The second theory argues that the target model can explain the behaviour of OPEC by using the target revenue model, which shows that the supply curve of oil is backwards-bending as indicated in the diagram below ${ }^{1}$

Figure 3. 1: Backward-bending Supply Curve of oil

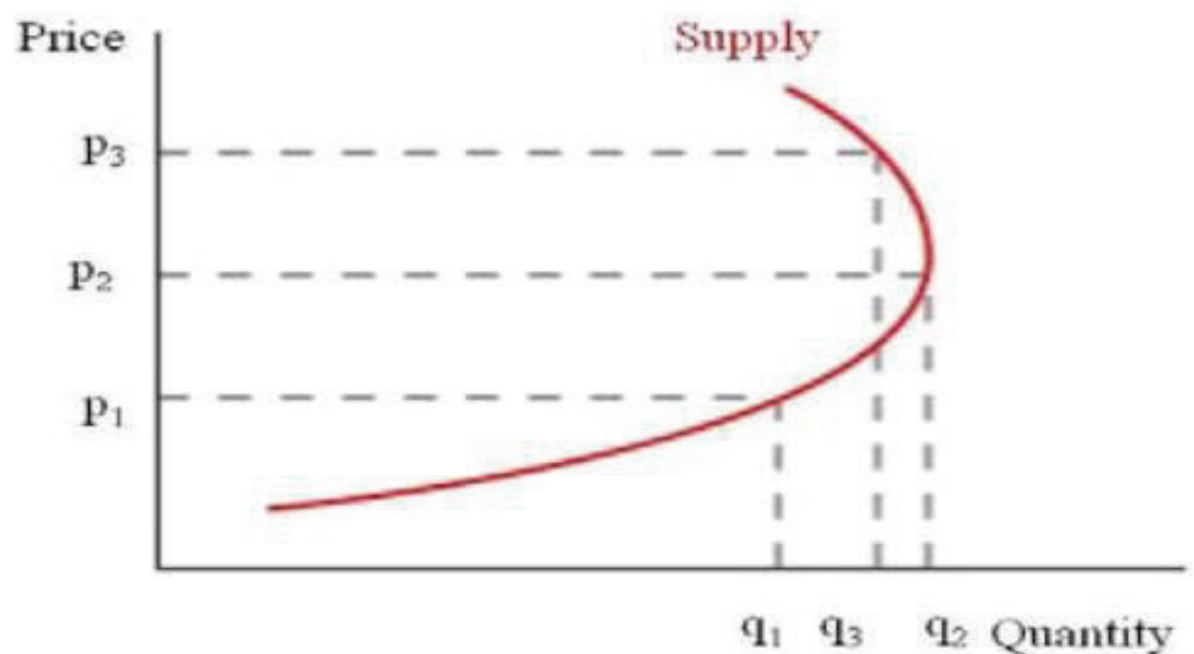

Source: Geswani (2012)

Alkhathlan, Gately and Javid (2013); OPEC (2013); Goswani (2012); Wesley (2010); Al-Qahtani, Balistreri and Dahl (2008); Alhajji (2004); Cremer and Salehi-Isfahani (1989) supported the view of the backwards bending supply curve. These studies contend that most of these oil-exporting economies already have a target of the level of oil revenue needed to meet up with the budgetary requirements of the nations. The cutback or the reduction in OPEC's production only occurred because the economies had already attained to their targeted revenue and as such reduced production at the increased oil price. The above figure depicts that when the price of oil increased from $\mathrm{P}_{1}$ to $\mathrm{P}_{2}$, there was a corresponding increase in the quantity of oil supplied. A further increase in price from $\mathrm{P}_{2}$ to $\mathrm{P}_{3}$ led to the cutback of oil provided by OPEC. As the targeted revenue had reached and as such, no more incentive for further oil production, the authors claimed. Alhajji, (2004) added that the above scenario characterises the situation of an imperfect market, whereby as supply increases with price, the producers in the course of exhibiting their market power, increase the price of the commodity much higher and at the same time reduce the quantity of the commodity supplied.

Al-Qahtani, Balistreri and Dahl (2008) added that the relatively lower oil price before the oil embargo shows the interaction between demand and the upward sloping oil supply curve of OPEC. Demand increased

\footnotetext{
${ }^{1}$ The second theory argues that OPEC's behaviour during the Yom Kippur War can best be explained using the target revenue model, which indicates that, the supply curve of oil is backward bending. See Goswani (2012); Al-Qahtani, Balistreri and Dahl (2008).
} 
due to the world economic growth, which shifted the demand curve far enough to intersect the backwards bending part of OPEC's supply curve at a very high price (Cremer and Salehi-Isfahani, 1989).

The conclusions of Griffin were consistent with the above analogy. OPEC's role was described in the study using the target revenue model as well. The theory argues on the basis that the investment needs of the economy determine the necessity of the oil revenue. It is the investment requirements of the budget that compels the members to determine oil production to increase the price. This theory further portrays that once the economy satisfies the investment target, and then there would be no more need for further production. The above supports the backwards bending supply curve in explaining OPEC behaviour during the 1972-1974 oil crises.

Critical examination of the models reveals that the wage rate reaches a certain level before the output drops because of a further increase in the wage rate. At that point, the worker is not willing to give up leisure for work, which led to a drop in output. In the period of OPEC's oil restriction, most studies (Sorkhabi, 2015; Hamilton 2011, 1983; Williams 2011, 2007, 1999 and Williamson, 1966) emphasise that it was the reduction in output due to the attack launched on the Israeli by Syria and Egypt. It was the reduction in production that led to the quadrupling of the price. None of the studies mentioned that these oil-exporting nations had already met their budgetary needs at the time before the production cut.

If the price had already increased to some degree before the cutback of the production, it can then be justified that perhaps, OPEC countries had already reached their targeted revenues and as such, not willing to make more revenue by cutting down production at higher prices. Nevertheless, that was not the case at all because it is unlikely that any of these oil-exporting countries would just desire a fixed level of revenue such that any income beyond that would result in a cut in oil production to substitute leisure for work. The above conclusion is highly justified further by the findings of IOGA, (2015) and Williams, (2011).

In contrast to all the above, Blinder and Rudd (2008); Hejny and Nielsen (2003) viewed the 1972 - 1974 oil price event differently as they interpreted the history through the lens of the shock supply model. They noted that both the aggregate demand shock and aggregate supply effects were the best to explain the high stagflation events with the aggregate demand shocks having more significant effects. The supply shocks events on impact, simultaneously move both the price level and the output degree in the opposite direction, thereby leading to stagflation. Hejny and Nielsen (2003) further stressed that it is usually tough to address the effects of stagflation on any economy and added that the occurrence of the energy crisis is because of different balance existing between domestic production and domestic demand.

\section{Figure 3. 2: Supply shocks in aggregate supply and aggregate demand framework}

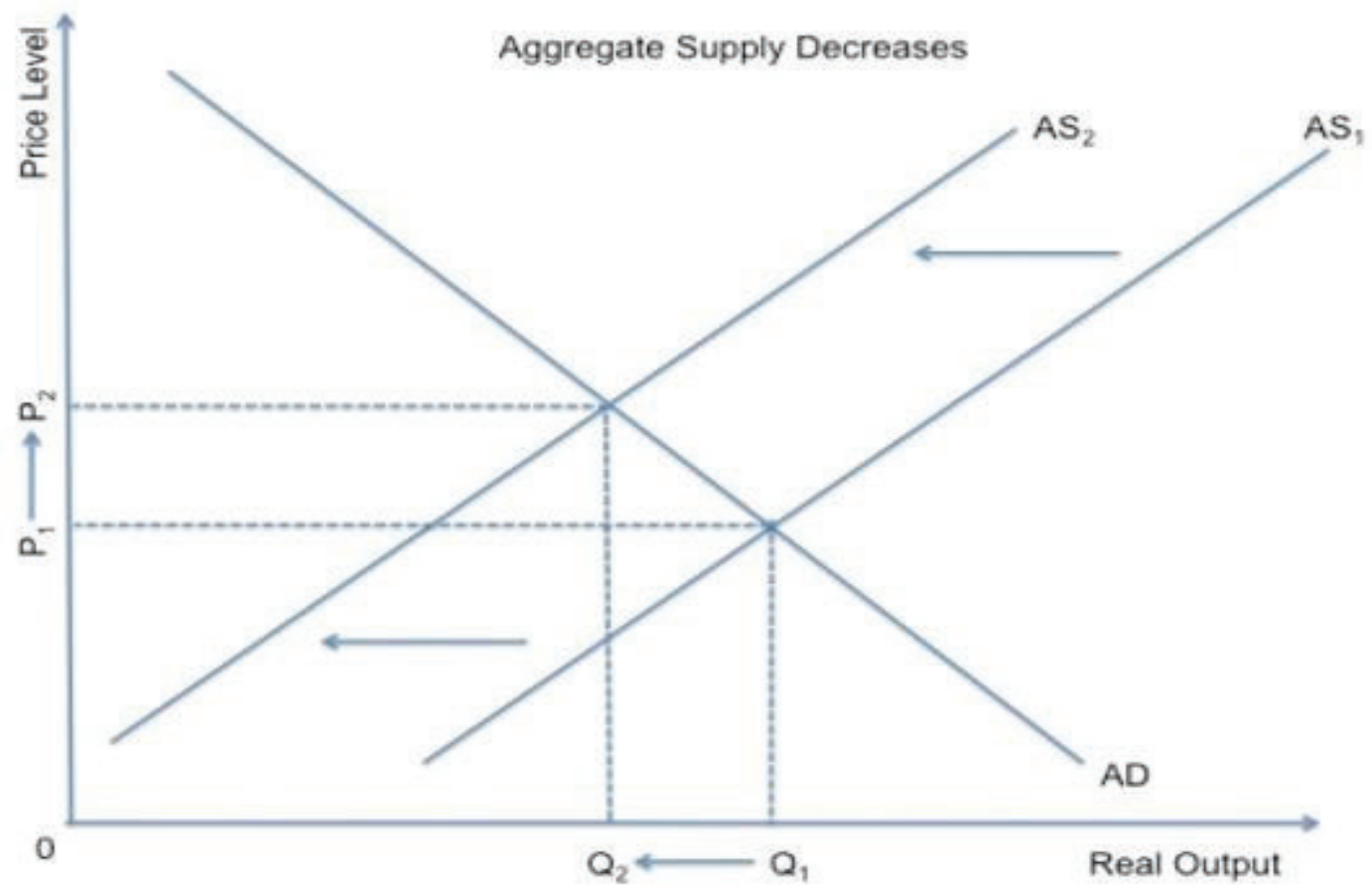

\section{Source: Blinder and Rudd (2008)}

The diagram shows a standard aggregate demand and aggregate supply, whereby the aggregate supply 
curve, shifts inwards along a stationary aggregate demand curve. The outcome is stagflation because price increased while output decreased drastically ${ }^{1}$. In using this phenomenon to explain the OPEC embargo, Blinder and Rudd (2008) did not explicitly state why the reduction in output by OPEC, which led to the increase in the price of oil as demonstrated in the model.

Al-Yousef (1998) posits non-existence of competition amongst OPEC members who work in a group to maximise their profits and does not set prices as the residual supplier. The models in the study assume that the cartel is in charge of the oil market whose members co-operate, to maximise profits jointly. In like manner, several other authors such as Griffin (1985), Pindyck 2001 and Gately (1984), have described OPEC as a cartel who through the joint co-operation reduces the quantity of commodity supplied thereby causing prices to be higher than the marginal cost. Gately (1984) further contradicted the above assertion by portraying that increases in the price of oil were instead a natural consequence. Some researchers opposed the view that the oil embargo of 1973 to 1974 was a deliberate collusive act, and not a natural phenomenon as argued in the study of Gately (1984).

On the contrary, Alhajji and Huettner (2000), have a different view of the 1972 - 1974 oil price increase. They argued that an oil price increase of that period could be explained better by other factors apart from cartelization. They concluded that non-OPEC production outweighed OPEC production in the world oil market. They further were of the view that OPEC has never agreed on oil prices and production quotas among OPEC countries were never possible until 1983. One of the dominant characteristics of a cartel is the ability to punish defaulted members, which OPEC lacks.

\subsection{Quadrupling of Oil Price (1974 - 1978)}

After the Yom Kippur War had been characterised by doubling oil prices and reduction in oil production; the crude oil price increased moderately from $\$ 9.35$ per barrel to $\$ 14.95$ per barrel $^{2}$. ChartsBin (2014) posits that oil price was approximate $\$ 11.58$ per barrel in 1974 to $\$ 14.02$ per barrel in 1978. The findings of IOGA, (2015) revealed that the oil price averaged between $\$ 11.20$ per barrel in 1974 , to $\$ 14.95$ per barrel in 1978 ; this finding was similar to those of ChartsBin, (2014). More so, Goswami (2012) shows a detailed account of the new regime in which Saudi Arabia took a different stand and bore the burden of change to the drastic reduction in the demand for oil production from OPEC. Saudi Arabia realised that the severe economic depression in the western countries due to the OPEC embargo could threaten its members economically and politically in the end and so bargained to stabilise the oil price in the world oil market. The position of Saudi Arabia in OPEC was motivated because of the Middle Eastern politics development. However, the exact stable price maintained at that period, not specified at all by these authors.

Goswami, (2012) instead emphasised that between 1974 -1979, oil prices were determined collectively after coordination and consultation among the four leading OPEC members, namely: Saudi Arabia, Iran, Iraq and Kuwait. Although the leading position within OPEC was highly enjoyed by Saudi Arabia. The kingdom acquired such position due to its great production capacity, very high oil reserves and, which still enables them to cope amid oil price fluctuations ${ }^{3}$. The prices were relatively flat, ranging from $\$ 12.52$ per barrel to $\$ 14.57$ per barrel (Williams 2011 and 1999). Oil price in this period ranged from $\$ 12.21$ per barrel to $\$ 13.55$ per barrel (Moffat, 2008). The study was highly consistent with the findings of (Williams, 2007).

On the other hand, Wesley, 2010 noted that oil price was undistorted in real terms during this period but did not categorically state the actual price figures as well. In the same vein, Blinder \& Rudd (2008) also maintained that the real price of crude oil remained roughly flat from 1974 to 1978 but was not categorical as to the actual price range. Firstly, the initial oil shock empowered most of the OPEC governments to have control over their crude oil resources. Secondly, the oil crisis encouraged most of the western economies to search for another alternative to oil all over the world. Finally, the center of policymaking on the price of oil shifted to the Middle East from the United States. In general, however, the price of oil during this period was changing according to almost all the above-examined authors but the period was also characterised as that of increasing oil price.

\subsection{The Iranian Upheaval (1978 - 1980)}

The oil embargo was followed immediately by the Iranian upheaval between 1978 to 1980. Mcmohon (2015) and IOGA (2015) showed that the price of oil increased rapidly from \$14.95 per barrel in 1978 to $\$ 37.42$ per barrel in 1980. The reasons for the drastic increase in oil price were not disclosed in these studies. During the oil embargo of the OPEC countries in 1973, the Iranian economy had the highest oil production in that period. In 1978 , this act led to the tremendous public demonstrations, thus leading to the 7 per cent reduction in the Iranian

\footnotetext{
${ }^{1}$ Stagflation occurs when there is high inflation and high unemployment in an economy; in the model above, stagflation occur because oil price increased while output decreased. See Blinder and Rudd (2008).

${ }^{2}$ After the Yom Kippur War, oil price increased moderately from $\$ 9.35$ per barrel to $\$ 14.95$ per barrel. See Mcmohan, (2015).

${ }^{3}$ Saudi Arabia enjoyed the leading position in OPEC due to its great production capacity and very high oil reserves. See Goswami, (2012).
} 
oil production as at January 1979 before Sheikh Khomeini took over power from Shah ${ }^{1}$. Nevertheless, Saudi Arabia increased its oil production capacity, which made up for the lost Iranian oil production (Hamilton, 2011). The oil price movements during the Iranian crisis were not categorical, and neither were the effects of the increase of Saudi Arabia's oil production on price stipulated.

Hejny, (2003) was of the view that the Iranian riot had the same effect with those of 1973 oil price increase of the OPEC embargo as the price of oil was on a very high side during the period. The crisis in Iran, is one of the major oil exporters, was based on political disturbance as well as the rationing methods used during the period. The study posits that the oil crisis adversely affected the consumption of petroleum due to some adopted strategies, for instance, efficient usage of oil even at that high price as well as industrial developments. The decline in the demand for oil importation led to a decrease in the oil price, which inadvertently brought about the end of the second oil disaster, just like the findings of Hamilton, (2011), the specific price movement, not discussed.

Conversely, Graefe, (2013) posited that the doubling of oil price was because of the increase in the demand for oil. Such demand increase was also because of the growth in the world economy and due to the drastic increase in the precautionary demand for oil. The very high inflation rate was the resultant effect of the oil price increase during this period. Additionally, the study maintained that there was a drastic decline in oil production due to the Iranian revolution, which may not be the only reason why the oil price increased. Relatively, speculative hoarding spurred because of fear of further disruption. Similarly, Haryono (2012) was highly consistent with the above as it laid more emphasis on the relationship between political development and the precautionary demand for oil as well. The precautionary demand for oil is the application of oil rising because of the future expectations of the markets about supply and demand.

In like manner, Graefe, (2013); Barsky and Kilian (2002) also argued that the persistent oil price increase at the period be only possible because of excess demand in the oil market. Such excess demand was due to favourable macroeconomic conditions such as reduced rate of interest, economic growth, and development. The increase in the oil price between 1979 to 1980 was because of the precautionary demand for oil due to increase in uncertainty as regards to the supply of oil in the future and the expectation of the use of oil in the future. Specifically, Barsky and Kilian (2002) stressed that oil price increased from \$19 per barrel to \$25 per barrel; it rose further to $\$ 34$ per barrel in April 1980. By December 1981, oil price increased to the zenith of about $\$ 39$ per barrel due to the precautionary demand for oil, which was responding to the uncertainty rise about the request, and supply of oil in future.

Kilian (2008) first introduced the speculative demand shock or the precautionary demand shock in 2009 and originally derived from the structural decomposition of the real prices of oil. The effects of the oil shock on real oil prices and the macroeconomic aggregates depends on the type of shock accountable for the fluctuation. The precautionary demand shock found to have an instant and significant effect on the real price of crude oil. Previous oil crises were also because of these movements, contrary to the traditional assumptions, which believed that supply shock was responsible for the oil price fluctuations (Filis et al. 2011; Kilian 2008).

Barsky and Kilian (2004) noted that most of the crisis in the main oil-manufacturing regions happened at the same time as the precautionary demand shock. In trying to establish the link between recessions and most oil price increase, discovered that in the 70 s and ' 80 s, oil has been accountable for all the backwardness in production. The oil price increase of 1979 triggered the recession in 1980, whereas the 1983 recession came before the oil price increase of those periods. On the contrary, the 1981 recession occurred during the term of decline in the oil price. The above assertions depict that there is a strong relationship between oil price, whether increasing or decreasing and economic recessions. The precise oil price movement not specified, as well.

Moffat (2008) and Williams (1999) had different opinions altogether from the above point of view. The studies highly specified that the high oil price during the Iranian upheaval brought about the decline in the demand for oil and which subsequently, led to the fall in oil price as predicted by the then minister of petroleum, Ahmed Yamani of Saudi Arabia. Many factors were responsible for the low oil demand, which led to the oil price decline. Reacting to the rising oil prices, many new houses, insulated while improving the insulation of the older houses. More energy efficiency, used in the industrial sector while the vehicles with very high-energy efficiency, produced and increased oil manufacture and exploration from non-OPEC countries. All these and the global economic depression reduced oil demand and in turn, lowered oil price. It was unfortunate for OPEC because the world economic recession was not permanent. As soon as it was over, the insulated houses, not removed, neither was the energy-efficient machines changed. Nevertheless, the level of reduction in the price of oil not indicated.

On the contrary, Williams $(2011,2007)$ further argued that since the history of World War II, the high oil price came because of the Iranian revolution. The production of crude oil was less by 10 per cent in 1979 due to

\footnotetext{
${ }^{1}$ The increased production of oil by Iran during the oil embargo in 1973 metamorphosed to the Iranian crisis, which further led to the 7\% reduction in the Iranian oil production in 1979. See Hamilton, (2011).
} 
the revolution. The decline in production due to the crisis increased the oil price to more than twice over from $\$ 14$ per barrel in 1978 to \$35 per barrel in 1981. The study of Alhajji (2004) was highly in the same resonance with the above as it posits that the period was the second oil crisis, which was responsible for the doubling of oil price to $\$ 93.41$ per barrel in 1979 from $\$ 46.13$ per barrel in 1978 . This period was also categorised as the initial attempt to influence the oil price in the world oil market by the OPEC.

Reisdorf, (2008) view the period differently as the transformation of the Iranian Kingdom from a Monarchy government to the Islamic Republic of which the process brought about the drastic drop in the oil production by the two nations. It brought about the loss of about 2.5 million barrels of oil in one day. There were complete price differentials in the above studies, but both acknowledged the fact that there was an increase in the oil price of about twice the initial price due to the second oil crisis.

Goswami (2012) and Gately (1984) thought that there are two surrounding theories to the explanation of the oil price surge of 1979 to 1980 . The first theory posits that OPEC deliberately used the oil revolution in Iran to make more gain from the oil market, which was already tight. The Organisation unilaterally made Saudi Arabia to cut back its oil production, thereby creating excess demand for oil globally. As a result, the blame shifts to the restriction of oil production and not to the Iranian revolution. On the contrary, Gately (1984) argued that both the oil price increase and the reduction in oil production from 1979 to 1980 be a mere extension of the Yom Kippur War of the 1972 to 1974 oil crisis ${ }^{1}$.

Tthe second theory consists of two opinions. The initial interpretation was that Saudi Arabia was the main actor that caused the oil price to increase due to some political constraints at the time. The alternative view argues that the rise in oil price was because of the principles of demand and supply and further posited that OPEC was not important as an organisation (Goswami, 2012). The dominant producer theory of OPEC was adopted by Al-Qahtani, Balistreri and Dahl (2008); Al-Yousef, (1998); Griffin and Tecee (1983) in explaining the above scenario. The studies suggest that the monopoly power of OPEC was in Saudi Arabia being the highest oil producer while the other OPEC members and non-OPEC members behave like a competitive fringe ${ }^{2}$.

\subsection{The Iraq - Iran War (1980 - 1981)}

While the oil production in Iran was still picking up and recovering from the revolution crisis, the war against Iran in 1980 by Iraq further increased the loss in the world's oil production by 6 per cent. Considering the Iranian upheaval and the Iraq-Iran battle as a single of two distinct events depends on the measure used for the oil price. While the United States producer price index for crude oil views it as two different events, the WTI considered the doubling of the oil price at those periods to be an extended event from 1978 to 1981 (Hamilton, 2011).

Responding to the cost increase during this period led to the imposition of price control by the United States on the crude oil, which is, produced locally made the United States oil consumers to pay more for imported oil. It, therefore, reduced the level of importation oil dependency by the United States in 1979 - 1980 and as such, not affected by the price increase caused by the Iranian upheaval and that of the Iran - Iraq war. It was seen as a bad policy as it has other effects aside subsidising the domestic oil industry for the United States consumers (Williams, 2011; Reisdorf, 2008; Moffat, 2008).

On the same note, Williams, (2011, 2007 and 1999) and Reisdorf, (2008) posits that there was chaos in the Iranian oil production during the revolution in Iran, it was further aggravated in 1980 when Iraq attacked Iran. Consequently, oil production was lower by 6.5 million barrels in one day, which was about 10 Percent lower. The combined effects of both the Iran - Iraq battle and the Iranian revolt triggered the price of oil to increase more than twice. Specifically, oil price increased in 1978 from $\$ 14.00$ to $\$ 35.00$ in 1981 . The outlined effect in this study is highly consistent with those of Hamilton, (2011).

On the contrary, Mcmahon (2015) showed that oil price in 1980 was $\$ 37.42$ per barrel and declined to $\$ 35.75$ per barrel in 1981 .

The reasons for the decline in oil price not stipulated. It is also unlikely for the price of oil to be decreasing at that period given the fact that there were disruptions in the oil production at the period due to the Iranian revolution, subsequently followed by the Iraq - Iran war. The shortages in the world oil production from these two major oil producers would be likely to lead to the increasing price of oil rather than oil price decrease as claimed by the author.

\subsection{The Great Fall in Oil Price (1981-1986)}

The drastic rise in oil price due to the two great crises in the world; the Yom Kippur war and the Iranian revolution preceded a sharp decline in the world's demand for oil between 1981 to 1986 . During the period, oil demand fell sharply by about 20 per cent. Many factors were responsible for the reduction in the demand for

\footnotetext{
${ }^{1}$ Both the oil price increase and the reduction in oil production from 1979 to 1980 is seen as a mere extension of the Yom Kippur War of the 1972 to 1974 oil crisis. See Gately, (1984).

${ }^{2}$ Competitive fringe is a term used in an organization to describe a smaller unit of any industry that takes prices as given by the dominant firm.
} 
OPEC's oil. The reason was partly the recession, which came after the drastic increase in the oil price of the previous periods as the whole world was still recovering from the oil price shocks. The second view was also due to the drop by 19 per cent in the ratio of energy consumed about the Gross National Product. The use of other alternative sources of energy also increased drastically while the share of the world's energy consumption fell so drastically at the period (Goswami, 2012; Flavin, 1985).

However, the above findings were in line with the conclusions of IOGA (2015). They maintain that in the $80 \mathrm{~s}$, one of the highest importers of crude oil products, the United States of America, improved and became more energy-efficient regarding its industrial processes, also improved in automobiles with higher gas mileage and in the insulation of homes. All these, in turn, reduced drastically its demand for oil at that period. The study posits that the production quotas set by OPEC were not enough to stabilise the oil price as most of the OPEC countries produce more than their given quotas. IOGA, (2015) outlined the oil price in this period as $\$ 37.42$ per barrel in 1980, \$35.00 per barrel in 1981, \$31.55 per barrel in 1982, \$29.00 per barrel in 1983, \$27.50 in 1984 , $\$ 26.50$ per barrel in 1985 . However, the increase in oil production further forced the oil price to as low as $\$ 14.68$ per barrel in 1986 . The above showed that there was a continuous decline in the price of oil from 1981 to 1986.

Hamilton (2011) and Alhajji (2004) were highly consistent with the above position. The studies were of the view that oil production from Iran and Iraq reduced due to the war experience in those kingdoms. Coincidentally, the world's consumption of petroleum products reduced significantly in the 1980s. Saudi Arabia voluntarily reduced oil production as well around 1981 to 1985, which was not enough to offset the 25 per cent sharp decline in the oil demand. In 1986, Saudi Arabia opened its oil valve again and flooded the market with more oil production, which inadvertently, forced the oil price to fall from \$27 per barrel in 1985 to \$12 per barrel in 1986.

Similarly, Barsky and Kilian (2002) supported this view by enunciating that the efforts of the Saudi Arabia Kingdom to reduce production at that period to increase the price of oil were highly frustrated by the weak in demand for oil. While new oil producers joined the oil market, the new ones expanded their oil production, thereby increasing oil supply and inadvertently leading to the decline in oil price.

Barsky and Kilian 2002 posits that the resultant effects of the changes in oil prices in the form of a drastic decrease in the demand for oil truly falls in line with the Hotelling model. This model enables the consumers to go to the producer from which they can conveniently purchase their product ${ }^{1}$. In the same vein, Al-Yousef (1998) employed the competitive model to explain Saudi Arabia's role during the period.

\subsection{The First Persian Gulf Battle (1990 - 1991)}

Hardly had the Iraq-Iran upheaval stopped; then the first Persian Gulf battle erupted in the Persian Gulf region (DeVore, 2009). This period has to do with the improvement in the oil production techniques as well as improvement in drilling technology. There was a drastic increase in the price of oil at this time because of the invasion of Kuwait by the Kingdom of Iraq and due to the Persian Gulf War. Oil price increased from \$18.33 per barrel in 1989 to $\$ 23.19$ in 1990 (IOGA, 2015). This is highly consistent with the study of Hamilton (2011). It posits that about 9 per cent of the total world oil production came from Iraq and Kuwait at this period. There was a threat in August 1990 with Kuwait's invasion by Iraq. The price of oil increased about twice the initial price within the short period but stabilised some months after as Saudi Arabia increased its oil production capacity. Although Hamilton, (2011) maintained that there was an oil price increase at the period, the actual price movements were not featured.

However, contrary to the above, Goswami, (2012) view this period differently as the time of oil and blood amid high politics and decreased oil price due to the invasion of Kuwait by Iraq at the commencement of 1990. The invasion of Kuwait was highly politically and regionally oriented. Saddam Hussein's other objective was to liberate Iraq from the economic calamity threatening the Kingdom due to the low prices of oil in the world oil market. To improve the oil revenue, Iraq demanded that OPEC members promulgate policies for oil production to raise the oil price. Kuwait and the United Arab Emirate failed to adhere to this by producing more to recompense the loss in oil revenues caused by a decrease in oil price.

The motivation for supporting decreased oil prices was rooted in the equation that low oil prices trigger high demand for oil, which will, in turn, lead to the world economic expansion and economic growth. Though low oil prices highly jeopardised the economic interests of Iraq, thereby resulting in the use of Iraqi's military against Kuwait. The imposed oil export embargo on the two economies further caused an increase in oil price at the period (Goswami, 2012).

There was an increase in the world oil consumption from 1990 to 1997 and Russia reduced its oil production, oil price began to recover but did not last because OPEC continued to increase its oil production. Also, the rapid growth in the Asian economies and their oil consumption declined drastically within a space of

\footnotetext{
${ }^{1}$ The Hoteling model enables the consumers to go to the producer from which they can conveniently purchase their product. See Barsky and Kilian (2002).
} 
sixteen years for the first time in 1998. Oil price dropped from $\$ 19.09$ to $\$ 12.72$ per barrel due to the corresponding decline in oil consumption and 10 per cent increase in oil production at the time (Goswami, 2012; Hamilton, 2011; Williams, 2011; Reisdorf, 2008; Moffat, 2008 and Ahhajji, 2008).

\subsection{The Second Persian Gulf War and the Venezuelan Conflict (2003)}

There was a reduction of about 2.1 million barrel per day in 2002 of oil production from Venezuela due to a general strike. It follows shortly by an additional reduction of about 2.2 million-barrel-per-day after the attack on the Iraqi economy by the United States. Hamilton (2011) argued that the above events could be characterised as geopolitical events, while Killian (2008) claimed that the events instead be classified as part of the oil shocks of the post-war era. Although there was an increase in oil price, which did not last between 2002 and 2003, the figures for the oil price changes, not identified.

The above was highly inconsistent with the studies of Williams, (2011); Moffat, (2008) and Alhajji, (2004). They conclude that due to the strike in Venezuela and the Iraq attack by the United States, significant shortage in the oil production occurred leading to an excess oil price increase of $\$ 40$ to $\$ 50$ barrels per day. Also, the oil price increase at the period was due to the high growth rate of the Asian economies as well as the hurricanes in the year 2005 and the refinery problems in the United States. Specifically, IOGA, (2015) stipulated that oil price increase from \$22.81 in 2002, \$27.69 in 2003, \$37.41 in 2004 to about \$50.04 in 2005 which is highly consistent with the above findings.

\subsection{Worldwide Financial Decay and Stagnating Supply of Oil (2007 -2008)}

After the Second Persian Gulf Battle and the Venezuelan Conflict in 2003 comes the worldwide financial decay and stagnating supply of oil from 2007 to 2008. Hough and Barton, (2016) in the examination of oil price outlook and trends disclosed that the price of oil continued to increase from $\$ 90$ per barrel in 2007 and persisted until it reached its peak price of an average of $\$ 146.08$ per barrel in July $2008^{1}$. Similarly, this is consistent with the conclusions of (The New York Times, 2008) as being the peak price in the series.

As of November 2008 , oil price became relatively stable at $\$ 40-\$ 50$ per barrel and later, rapidly increased to $\$ 60$ per barrel in June 2009. Also, IOGA (2015) indicated that there was an increase in the price of oil from an average of $\$ 64.20$ per barrel in 2007 to the mean price of $\$ 91.48$ in 2008 . However, the actual cause of the oil price increases not specified.

This period indicates a time of demand for oil increase and stagnating supply of oil. The growth in the world's consumption of oil in this period could not equate the oil production because, after 2005, oil production declined due to the political instability in Iraq and Nigeria at the period ${ }^{2}$. Most oil-producing countries like Mexico, Indonesia, the North Sea, also experience a drastic decline in oil production at the period (Hamilton, 2011). This conclusion is highly consistent with those of Roberts, (2018), who revealed that as at that 2008, the oil price was very high because crude oil production and supply was relatively low.

The Kingdom of Saudi Arabia, which accounts for about 13 per cent of total world oil production in 2005 , decreased its oil production by 850,000 barrels per day in 2007 , which is lower than the 2005 production. Saudi Arabia was indeed an active producer of oil in the $80 \mathrm{~s}$ and the $90 \mathrm{~s}$ as well but had reduced production drastically during the 2008 - 2009 periods, shortly after the global financial crisis in the same period (Hamilton, 2011).

The decrease in oil production leading to the increase in oil price at the period was highly inconsistent with the economic theory, which states that at high prices, producers would be very willing to supply more, all things being equal $^{3}$. It also violated the law of supply, which states that at higher prices, producers would be very willing to supply more quantities to the market to expand the business. The law of demand did not hold in this period as well as it states that at higher prices, demand decreases and vice versa ${ }^{4}$. This period was instead characterised, according to Hamilton (2011) at the time of the increase in oil demand and stagnating supply thereby exhibiting abnormal demand and supply curves.

Different theories surround the decline in Saudi Arabia's oil production at this period. Ghawar field reached its peak since it has been in operation since 1951and has accounted for about 6 per cent of the entire world's oil production, Simmons (2005) posits. The year 2009 was tagged a year to regret by Cohen (2009) as there was a drastic decline in the oil revenue of the Republic of Yemen. Afterwards, the worst environmental disaster in the United States, which was an oil spill, then followed as well as the death of one of the icons of the peak oil movement, Matthew R. Simmons (Hamilton, 2011; Kaminski, 2010; Schall, 2009a). Hamilton, (2009b) still

\footnotetext{
${ }^{1}$ Oil price reached its peak in 2008 as oil traded at $\$ 146.08$ per barrel. The highest in the whole series of oil price fluctuations. See Hough and Barton, (2016) and The New York Times, (2008).

${ }^{2}$ The growth in the world's consumption of oil in this period could not equate the oil production due to political instability in most of the oil producing countries. See Hamilton, (2011).

${ }^{3}$ The decrease in oil production leading to the increase in oil price at the period was highly inconsistent with the economic theory, which states that at high prices, producers would be very willing to supply more, all things being equal.

${ }^{4}$ The law of demand did not hold in this period as well as it states that at higher prices, demand decreases and vice versa. See Singh, (2016).
} 
posits that the decline in oil production just coincided with the increase in oil price ${ }^{1}$. Further argues that political uncertainty and maladministration in Iran, Iraq, Russia, Venezuela, Nigeria and Mexico, aside environmental considerations were also contributory factors to the decline in oil production at the period.

The different theory argues that as many analysts assumed, it would not be in the best interest of the OPEC members to have increased their oil production at this period. Gately and Simmons had already predicted that just as many analysts predicted before, the Kingdom of Saudi Arabia would fail to increase their oil production ${ }^{2}$. Irrespective of the fact that oil production has drastically declined over this period, oil demand continued to rise as China increased its oil consumption within 2005 and 2007 by 840,000 barrel each day. As a result, oil price increased to $\$ 142$ per barrel in 2008, \$145 per barrel in July 2008 as against \$55 per barrel in 2005. The 20072008 oil price increase and the 2007 United States recession were the greatest ever, since the post-war period. Although, the financial crisis was the main attribute to the economic downturn at the period ${ }^{3}$.

\subsection{Unimaginable Shock in Oil Price $(2010$ - 2013)}

The effects of the global financial crisis and the decline in oil production led to a persistent increase in oil prices. From August to December 2010, oil price rose from about $\$ 75$ per barrel to about $\$ 90$ per barrel. In 2011, oil price increased further to $\$ 125$ per barrel due to the civil war that broke up in Libya. The period was the highest increase in oil price after the peak of $2008^{4}$.

The price of oil remained much unstable within the range of $\$ 100$ - $\$ 110$ per barrel during the rest of the year, 2011. The price further increased above \$120 per barrel around June 2012. As at April 2013, the price of oil fell relatively to $\$ 100$ per barrel, but the growing tension in Syria pushed the oil price further to more than $\$ 115$ per barrel lately in summer, 2013. Rising demand for oil characterised the latter part of 2013. There was a disruption in oil supply due to the political instability in Iraq and Libya but the United States and OPEC increasing oil supply during that period contributed to the moderately stable oil price (Hough \& Barton 2016). Oil price during this time was relatively high due to the aftereffect of the global financial meltdown during the previous cycle and because the supply and the demand for oil were still in disequilibrium. However, increasing oil price dominates the period.

\subsection{The Most Recent Slump in Oil Price Amidst COVID-19 Pandemic (2014 - 2020)}

Recently, precisely from the year 2014, 'the dancing steps' of increasing oil price began to change in the global oil market as the oil price continues to decline since then thereby keeping most oil-dependent economies in disarray, as to what next? That is, those countries whose primary source of revenue generation relies mainly on oil. The issue of the price war between Saudi Arabia and Russia and the decline in the global economic activities due the COVID-19 pandemic are the two major forces that has adversely affected the global oil market in $2020^{5}$. Most of these oil-dependent economies already have their income target aimed at meeting with their budgetary provisions, which were prepared based on certain fixed oil prices. More so, the fiscal break-even price needed to balance the budget by some of the OPEC countries include Nigeria - \$123 per barrel; Angola - \$110 per barrel, Saudi Arabia - \$106 per barrel, Iran - \$87 per barrel, Iraq - \$81.00 per barrel, United Arab Emirate - \$73 per barrel, Algeria - \$96 per barrel, Kuwait - \$49 per barrel, Qatar - \$56 per barrel, Venezuela - \$117.50 per barrel and Libya - \$269 per barrel ${ }^{6}$. Consistently, Edwards (2020) outlined the breakeven oil price as: \$91 for Saudi Arabia, Oman - \$82, Qatar - \$55, Iraq - \$60, Iran - \$195, Nigeria - \$144 per barrel, Libya - \$100 per barrel, Angola - \$55 per barrel and Algeria needs \$109 per barrel to balance their budgets. Other oil exporting countries like U.S, Norway and Canada would require oil price of $\$ 48, \$ 27$ and $\$ 60$ per barrel to thrive amidst declining oil price.

However, at the beginning of the year 2014, the oil price was between $\$ 105$ and $\$ 110$ per barrel but rapidly increased to $\$ 115$ per barrel. In August 2014, the price of oil drastically decreased to $\$ 100$ per barrel. It continued to decline due to oversupply on the part of most oil-producing economies and a drop in the oil demand growth. The increasing expansion of the shale oil and shale gas production in North America also led to the rapid development of the commercial stock. The oil price fell as low as \$47 per barrel in October 2014 and January 2015. As OPEC failed to reduce oil production, oil price further declined (Hough \& Barton 2016; Husain et al. 2015). Oil price fell as low as $\$ 42$ per barrel when Iraq, Saudi Arabia, and the United Arab Emirates supply

\footnotetext{
${ }^{1}$ Hamilton, (2009b) maintain that the decline in oil production and the corresponding increase in oil price was just a coincidence.

2 There was a prediction that the Kingdom of Saudi Arabia would fail to increase their oil production. See (Hamilton, 2011; Simmons, 2005)

${ }^{3}$ Since the Post-World War period, the increasing oil price of the 2007-2008 and the 2007 US recession were the greatest ever. Financial crisis was the main attribute to the economic downturn at the period. See (Hamilton, 2011; 2009a) and Williams, (2011).

${ }^{4}$ From August to December 2010, oil price rose from about $\$ 75$ per barrel to about $\$ 90$ per barrel. In 2011, oil price increased further to $\$ 125$ per barrel due to the civil war that broke up in Libya. The period was the highest increase in oil price after the peak of 2008 . See (Hough \& Barton 2016; Bowen, 2011; Williamson, 2011).

${ }^{5}$ See Kolakowski, (2020)

${ }^{6}$ The breakeven oil price needed by most oil dependent nations are higher than the prevailing oil price. See (Bentley et al., 2015 ; Fahey, 2015 and Rascouet, 2015).
} 
more oil at a rate higher than OPEC official supply target. The price of oil was as low as $\$ 27$ per barrel as at the early period of 2015 , and this was the lowest ever, since the year $2003^{1}$.

Similarly, Hough and Barton (2016) posit that the decline in the oil price since June 2014 to 2015 January was the highest for thirty decades ago but attributed the significant plunge in the oil price to be more of supplydriven rather than demand. The oil price has been volatile, increasing and decreasing at intervals but as at the end of the year 2015 , the price of oil was on the average of $\$ 41.85$ per barrel from the mean of $\$ 86.73$ per barrel in the year 2014 (IOGA, 2015).

However, as the world was trying to recover from the global financial crisis, most oil-producing economies were struggling to meet with oil production and the crisis in Iraq and Libya were hampering further oil supply, oil demand was rather on the increase within 2010 and 2014. The high oil price motivated the United States to employ the use of innovative hydraulic fracturing and horizontal drilling techniques to unlock huge quantities of oil from shale formations ${ }^{2}$. The new form of oil production more than doubled the United States Oil production from 2010 until date, thereby aiding oil supply to catch up with oil demand and even surpass it due to the negative impact of COVID-19 pandemic on the global economic activities. Saudi Arabia and other OPEC members failed to cut back production as previously the case to stabilise prices. As if that was not enough, Iran has started to produce and export more oil as sanctions on the economy are lifted (Mirhaydari, 2015). For the first time in th history of oil prices, the U.S. crude oil prices (WTI) was negative at $-\$ 37.63$ per barrel on Monday, the $20^{\text {th }}$ of April, 2020 (Edwards, 2020).

We keep observing the dynamics of both demand and supply since expectations are of paramount importance in this regard. If new data depicts an unanticipated increase in the production of oil or an unexpected decline in the demand for oil, price tends to fall as a result. On the contrary, a surprise decrease in oil supply or an unanticipated increase in oil demand will force the oil price to rise. Nevertheless, based on the above premise, in-so-far-as the oil supply outweighs oil demand, the price of oil will likely remain relatively lower than expected and vice versa.

\subsection{Factors Influencing the Rising and Falling of Oil Prices}

In recent history, oil price declined to about 44 per cent, partly due to the reduction in the economic activities of most of the consumer oil giants ${ }^{3}$. Some decades ago, there were alternating oil price cycles between increases and decreases inherent in the oil industry, but since 2014, the oil price cycle in the oil industry is on the decreasing side. It is imperative to identify some of the likely factors responsible for the constant movements in oil prices. Understanding these factors influencing the rising and falling of oil prices would be crucial to the critical assessment of the likely global macroeconomic impact were already discussed in the previous chapter.

Different researchers have different opinions as to the factors responsible for the oil price fluctuations in various episodes. To some researchers, the demand factor triggered most of the oil price volatility while some were of the view that supply factors were responsible. Others still posit that the mixture of both the demand and supply factor caused the oil price fluctuations in some episodes. From the literature so far, there is no consensus as to the rudiments of this recent oil price fall. Kitous et al. (2016); Baumeister and Kilian (2016); Bloomberg Business (2016a); IMF, Regional Economic Outlook, (2015); Arezki and Blanchard (2015); Yanar, (2014); Hamilton, (2011); Brown, 2006 and Al-Yousef, (1998) presents diverse views, as regards these factors.

In line with the above are the conclusions of Kristopher, (2015) that both the supply and demand factors were the cause of the oil price slump in recent years. The increase in OPEC and non-OPEC countries produBAction coincided with the decline in the oil demand from most of the greater oil consumers like the US, China, Japan. The United States importation of crude oil declined due to increasing in the production of shale oil in recent years. The Kingdom of Saudi Arabia oil export to the United States has dropped drastically by about 450,000.00 barrels per day, which is about 34 per cent (Lee, 2017). Shale oil has been in existence with high reserves since the $16^{\text {th }}$ century, not tapped due to its enormous cost of production. The real oil shock before 2014, coupled with improved technology through horizontal drilling and fracturing motivated the increase in the manufacture of oil in the United States. However, the increase in oil production forced the oil price to go down, lower than expected.

Al-Quadsi and Ali (2016); Krugman (2008) posits that one of the engineers of the oil price fluctuations in the oil market is speculations, which tends to ignite the oil price increase. For instance, the growth in the oil price of 2007 - 2008 was partly because some investors bought oil not as a commodity for its usage but rather as a financial asset. The study further asserts that the spike in oil price at that period was also due to increasing

\footnotetext{
${ }^{1}$ The price of oil went as low as $\$ 27$ per barrel as at the early period of 2015, and this was the lowest ever, since the year 2003. See (Hough \& Barton 2016).

${ }^{2}$ The high oil price motivated the United States to employ the use of innovative hydraulic fracturing and horizontal drilling techniques to unlock huge quantities of oil from shale formations. See (Mirhaydari, 2015).

${ }^{3}$ Oil price declined to about 44 percent recently, partly due to the reduction in the economic activities of most of the consumer oil giants. See Kilian, (2015)
} 
demand and not just due to production cut by the OPEC members. It was instead astonishing that the interest rate and the inflation rate at the period were relatively low. However, based on the recent decline in oil price, to less than $\$ 50$ per barrel since 2014, Al-Quadsi and Ali (2016) attributes it to the increase in the United States shale oil production for the past few years now, hence, an oversupply of oil.

Consistently, Husain et al. (2015) and Hinckley, (2015) opined that the recent decline in the oil price since 2014 was mainly due to supply factors, which was somewhat persistent. The declined could be traced to the demand factor too while the supply factor plays a dominant role in the recent oil price decline. Consistent with the above is the report from the Regional Economic Outlook: The Middle East and Central Asia, IMF 2015 that the recent decline in oil price is mainly supply-side oriented due to the shale oil production from North America and the oversupply of oil by the members of the OPEC. The lifted sanction on Iran also added to the oversupply in the oil market. Also, a weak global economic activity, which has led to a decline in demand for oil, is also a factor behind the sharp drop in the price of oil.

The above is highly consistent with the conclusions that, the supply factors were the cause of the increases in the oil price of the 1970s, especially those of the Yom Kippur War (Alkhathlan, Gately and Javid 2013; Goswani 2012; Williams 2011, 2007 and 1999; Pindyck 2001).

Based on the above premise, the supply factor is the most important factor responsible for both the oil price fluctuation of the Yom Kippur War and those of the recent oil shocks. The only distinction in both periods is that while increasing oil price characterised the fluctuations during the Yom Kippur War, the recent oil price volatility is mainly decreasing oil prices. The decreasing oil price affects the oil-exporting nations regarding meeting up with the budgetary needs of the economies since the contribution of oil to the revenue base is very high.

Lorusso and Peironi (2015) studied the causes and consequences of oil price fluctuations on the economy of the United Kingdom. Their results show that demand factor rather than supply has been responsible for the oil price movements in the 1970s. The direction of the oil price movements in the 70 s was mainly real shocks, that is, oil price increase. The recent oil price movements, while the negative oil price shock was not captured in the study.

Consistent with the above study, Bowler, (2015) maintained that weak demand contributed to the recent fall in oil price due to low economic growth. Further added that oversupply is another factor from both the OPEC members and an increase in the United States increasing shale oil production. From the preceding, both demand and the supply factor play a significant part in the movement of the oil prices from the 1970s to date.

\subsection{Demand Side}

On the Demand side, China, U.S., India, Europe could not accommodate more shipments due to storage gluts; as such, China cancelled over 10 shipments from Saudi Arabia in both April and May, 2020. Economic stability and the budgets of most of the oil exporting countries are threatened due the incessant decline in oil prices. The COVID-19 pandemic has also contributed immensely in destroying oil demand across the global energy market. Kilian (2015) posits that such decline was mainly due to the drastic reduction in the world's economic activity. Consistent with the above, Yanar, (2014) maintain that the low growth in most European countries and the recession expectations in Japan decreased oil demand, which in turn led to the oil price decline. Despite the increase in the business in the United States of about 50 per cent, oil consumption continued to decline since 2014. The drop in global oil consumption referred to as '2014 consumption surprise' was more than the projections that the International Energy Agency proposed in 2003.

More so, the then American president, Barack Obama and the Canadian prime minister, Justin Trudeau have taken a strong move to shift the United States and the Canadian economies to a very low carbon emission economies by reducing the amount of oil consumption. They are also very dedicated to providing clean, secure and renewable energy for the future generations who would continue with the carbon reduction strategy through the laid down policies ${ }^{1}$.

\subsection{Supply Side}

In early 2020, the oil and gas output from the United States of America increased by 57\% due to the advancement in the fracking technology ${ }^{2}$. The drastic increase in oil production in the U.S. dates back to 2014 as oil production rose from 5 million barrels in one day to about 9 million barrels per day. It also added to the total world oil production mainly from the hydraulic fracturing and horizontal drilling, making the United States be one of the highest oil producers in the world. The United States further plans to reduce its oil dependency by

\footnotetext{
${ }^{1}$ There was a strong move to shift the US and the Canadian economies to very low carbon emission economies by President Barack Obama and the Canadian Prime Minister, Justin Trudeau through the reduction in oil consumption. The nations are highly dedicated to providing a clean, secure and renewable energy for the future generations who are expected to continue with the carbon reduction strategy through the laid down policies. See (Goldenberg, 2016; Cox, 2015).

${ }^{2}$ See Kolakowski, (2020): History of Oil Prices.
} 
the year 2020 (Cox, 2015; Yanar, 2014)

According to Daniel (2016) and the International Energy Agency (IEA), (2016), the top ten oil-producing economies in the world, supply more than 66 per cent of the oil. The crude oil suppliers comprise of both OPEC members Iran, Iraq, Saudi Arabia, Kuwait, and Venezuela (founding members) Qatar, United Arab Emirates, Libya, Nigeria, Angola, Algeria, Ecuador and Gabon ${ }^{1}$. Non-OPEC countries comprise of Norway, United States, Russia, China, Mexico, Canada, Brazil. Some of the responsibilities of OPEC as an organisation are to coordinate the petroleum policy to protect the interest of its members, to ensure a stable oil price and consistent oil production, among others. Above all is to maximise their profit, which is the main aim of any business organisation.

OPEC is referred to as a cartel due to its role in giving production quotas to members and cutting down production to raise the oil price. Recently it is assumed that OPEC's role in the control of the production quotas among its members has failed since most researchers attribute the recent slump in crude oil prices to high oil production, which outweighs the oil demand. Increasing oil reserves and the rise in oil production in both OPEC and non-OPEC countries as a result of the discovery of the alternative procedures in oil production facilitated the decline in oil price ${ }^{2}$. However, it is evident that both demand and supply factors contributed to the continuous fall in the global oil prices.

\subsection{Quest for Renewable Energy}

Renewable energy, like wind, solar, biomass, hydropower and geothermal which are naturally replenishing fuel sources, providing clean, zero or low carbon emissions could also be a factor because the United States supply of electricity through the renewable energy sources increased from 8 per cent to 13 per cent between 2007 and 2014 . The development of most economies also leads to an increase in the need and demand for energy. Most countries, however, are already increasing their commitment toward the renewable energy (Harris and Roach, 2017; Motyka et al. 2017; World Energy Resources, 2016; IISD, 2014; Timmons et al.; 2014; Morales, 2010). 90 per cent of the electricity generation in the year 2015 emanated from renewables while it is expected that by the year 2040, zero-emission energy source would constitute about 60 per cent of installed capacity. More so, 195 countries signed a fair deal on greenhouse gas emissions during the United Nations Conference on climate change, resulting in the drastic growth in renewable energy in recent times. Most economies are in support of clean energy in the form of provision of renewable energy subsidies and taxation of carbon emissions (Motyka et al. 2017; Nachtigall and Rübbelke 2013).

Consistently, Klevnas et al. (2015) maintained that energy choices among different countries took different dimensions due to the nature of the fluctuations in oil prices in the world's oil market. This volatility has been constant over time and has culminated into the desire of most countries of the world to be clamouring for economic growth and at the same time trying to take part in the reduction of the hazardous GHG emissions that comes with the use of energy. Most countries are now concerned with the expansion of renewable energy use, improvement of energy efficiency and discouragement of wasteful consumption of fossils while ensuring the expansion of the supply of renewable energy. The need for climate change and conventional wisdom on the development of energy are based on the carbon reduction target of ensuring that the global warming is kept under $2^{\circ} \mathrm{C}$ which is achievable through the drastic reduction of the use of non-renewable energy (Papandreou and Ruzzenenti, 2015). Klevnas et al. (2015) also posit that the low-carbon policy ambition is capable of reducing oil prices by more than 50 per cent in the long term. There is an urgent need for the reduction of $\mathrm{CO} 2$ emissions in the environment while most economies are presently moving towards the expansion of international markets for the trading of green energy goods and services (OECD, 2015).

An effective climate change policy has a significant adverse effect on the price of oil in the world's oil market. Most economists are also considering whether carbon pricing in the form of taxing the emission of $\mathrm{CO}_{2}$ would be able to assist in the eradication of climate change even when the means of attaining to such goal is not yet certain (Papandreou and Ruzzenenti, 2015). Conversely, Nachtigall and Rübbelke (2013) and Sinn, (2012) maintained that empirically, there had not been any evidence to prove that the fall in oil prices in recent time was hinged on the green paradox ${ }^{3}$.

\footnotetext{
${ }^{1}$ The crude oil suppliers comprise of both OPEC members Iran, Iraq, Saudi Arabia, Kuwait, and Venezuela (founding members) Qatar, United Arab Emirates, Libya, Nigeria, Angola, Algeria, Ecuador and Gabon. See OPEC, (2018).

${ }^{2}$ Increasing oil reserves and the rise in oil production due to unconventional procedures in oil production facilitated in the decline in oil price. See Yanar, (2014).

${ }^{3}$ The green paradox entails that oil producers try as much as possible to increase oil production to prevent the effects of the expectations of the world policies supporting the reduction of fossil energy in future which, would in-turn hurt their revenue base.
} 


\subsection{Proposed Economic Model for Highly Oil Dependent Nations}
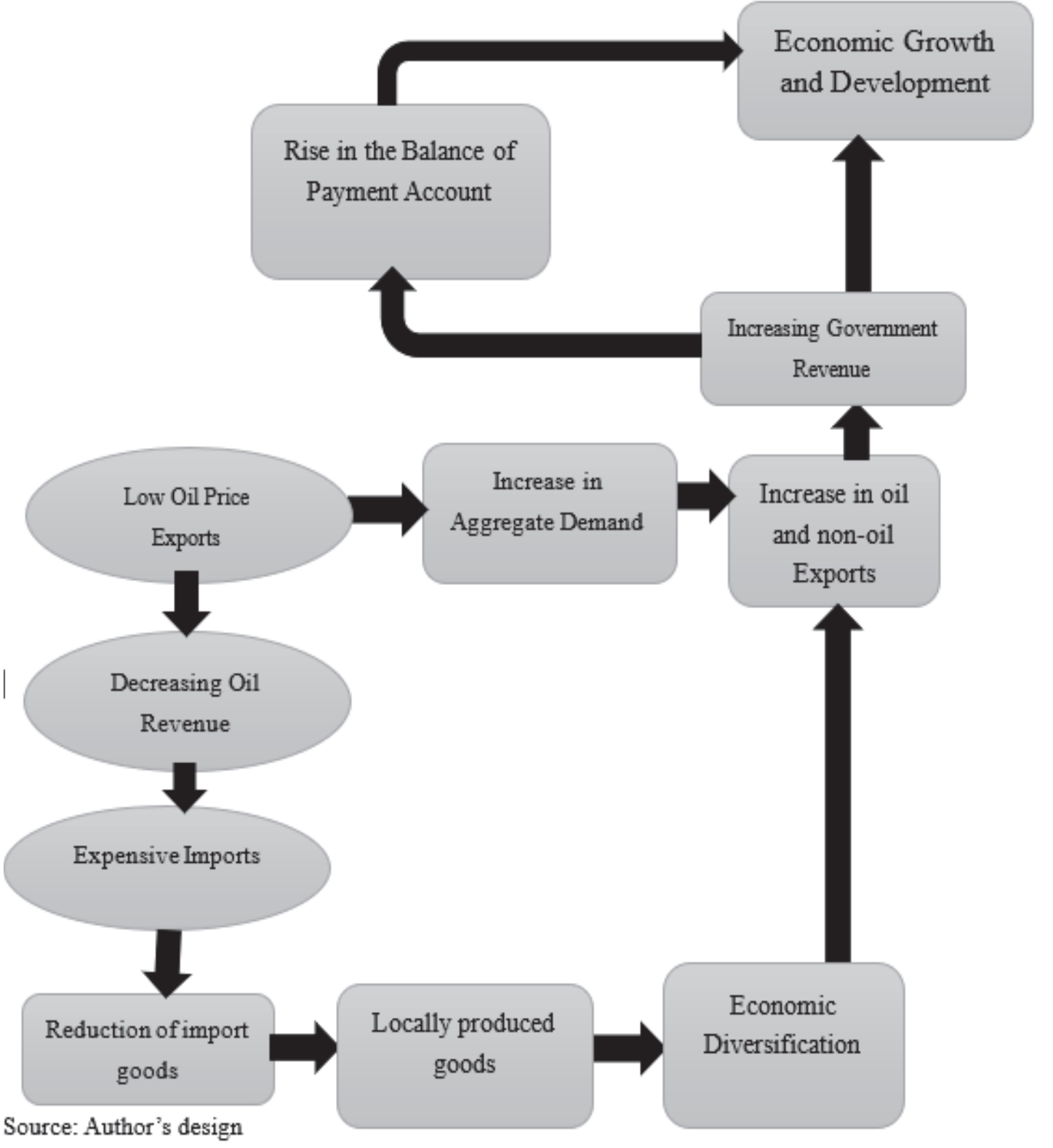

An economic model entails a simplified way of explaining the real world and its complex nature, which is often too difficult to understand literally. Economic models are usually subjective as different economists have different views and different judgements regarding the interpretation of what reality entails (Ouliaris, 2018).

Milton Friedman, among other economists, contends that economic models cannot just be tested by inquiring into the reality of its assumptions. These economists conclude that the validity of any economic model can be tested when it is capable of explaining and forecasting real-world activities. Friedman maintains that the ultimate test of any economic model is when it is faced with the data from the economy (Nicholson, 2007).

However, the economic model is aimed at closing the revenue gaps in most of the highly oil-dependent nations. The Norwegian economy already has an existing model which is working so effectively and as such do not need the above designed economic model.

The cheap oil exports led to the declining oil revenues, hence, the inability of these nations to meet with the fiscal needs of the economies. The weak exchange rate amid the low oil revenue makes import of consumer goods to be more expensive while increasing the aggregate demand for oil. The expensive imports led to the drastic reduction of import goods which should in-turn encourage the production of locally manufactured goods. This would lead to economic diversification whereby the economies are shifted away from a single product source of revenue by developing and investing on other sectors of the economies other than oil.

Although, the underlying assumptions upon which the above model is based entail that the nations are 
relying heavily on one major source of revenue (oil) and that the price of oil is decreasing, hence, decreasing oil revenue. We also assume that these economies are also endowed with other natural resources aside oil which the oil-exporters can also harness for a more diversified revenue base.

\subsection{Conclusion}

The global oil markets had witnessed different episodes of oil price fluctuations since the discovery of oil, which indicates that oil price is a dynamically transacted commodity across the globe. This study captured the historical perspective of crude oil fluctuation from 1946 to 2020. Although, the effect of this fluctuation differs across nations depending on whether the economy is oil-importing or oil-exporting. It also depends on the factors responsible for the fluctuation. The study reveals that while oil-importing nations tend to benefit more from declining oil prices, the oil-exporting nations lose more revenues to lower oil prices and as such, find it challenging to attain a fiscal balance. However, different episodes of crude oil fluctuations were reviewed, and it was revealed that the oil exporting countries enjoyed the benefits from increasing oil prices due to shortages in oil supply as a result of constant war, economic and political uncertainties from 1946 to 1980 . Oil price declined in 1981 to 1986 partly because of the recession, which came after the drastic increase in the oil price of the previous periods. After this period, oil price picked up due to the first and second Persian Gulf wars and the impact of the global financial crisis. The oil price continued to rise until 2014, when the "dancing steps" changed as oil price continued to drop till date. Both demand and supply factors were partly responsible for this incessant decline in oil price; coupled with the emergence of the unanticipated COVID-19 pandemic which ravaged the entire globe.

However, the major difference between the previous oil price shock and the present is that OPEC often meet and cut back oil production to revive oil price but in this present oil shock, the study concludes that the collusive power of this oligopoly has failed as OPEC has not been able to control the production quotas of its members. It is highly recommended that the appropriate policy response to oil price fluctuation is the one that would promote diversification of the revenue base of both the oil-importing and oil-exporting countries given that the "oil age" is gradually fizzling out. More so, many countries are already increasing their commitment towards the renewable sources of energy.

\section{REFERENCES}

Adelman, M.A. (1990) The First Oil Price Explosion 1971-1974. Available at: https://dspace.mit.edu/bitstream/handle/1721.1/50146/28596081.pdf?sequence=1 (Accessed: 10 April 2020).

Alhajji, A.F. (2004) Managing the price of crude oil - A case study of OPEC. Available at: http://www.spireenergy.com/wp-content/uploads/2013/11/OPEC-and-Crude-Oil-Prices.pdf (Accessed: 22 April 2020).

Alhajji, A.F. and Huettner, D. (2000) 'OPEC and World Crude Oil Markets from 1973 to 1994: Cartel, Oligopoly, or Competitive?', The Energy Journal, 21(3), pp. 31-60. doi: 10.5547/ISSN0195-6574-EJVol21-No3-2.

Al-Hamad, A. and Verleger, P.J. (2016) Oil and the Global Economy. Available at: http://group30.org/images/uploads/publications/OP94.pdf (Accessed: 5th January 2021).

Alkhathlan, K., Gately, D. and Javid, M. (2013) Analysis of Saudi Arabia's Behaviour within OPEC and the world oil market. Available at: http://www.econ.nyu.edu/dept/courses/gately/Saudi_Behavior_Feb2013.pdf (Accessed: 23 April 2020).

Al-Qahtani, A., Balistreri, E. and Dahl, C. (2008) Literature Review on Oil Market Modelling and OPEC's Behaviour. Division of Economics and Business, Colorado School of Mines, Golden Col. 80401. Available at: http://dahl.mines.edu/LitReviewOPEC.pdf (Accessed: 23 April 2020).

Al-Qudsi, S. and Ali, M. (2016) Economic Growth Implications of Oil Price Fluctuations: The GCC Context. Available at: https://www.dohainstitute.edu.qa/MEEA2016/Downloads/Sulayman\%20AlQudsi.pdf (Accessed: 17 July 2020).

Alquist, R., Kilian, L. and Vigfusson, R.J. (2013) 'Forecasting the Price of Oil.', Handbook of Economic Forecasting, 2, pp. 427-507.

Al-Yousef, N. (1998) Economic Models of OPEC behaviour and the role of Saudi Arabia. Availableat: https://www.surrey.ac.uk/economics/files/apaperspdf/SEED\%2094.pdf (Accessed: 23 April 2020).

Arezki, R. and Blanchard, O. (2015). "The 2014 oil price slump: Seven key questions". Available from: https://voxeu.org/article/2014-oil-price-slump-seven-key-questions [Accessed 26th July 2020].

Balli, E., Tras, M.F. and Sigeze, C. (2016) 'Impact of oil price on turkish macroeconomic variables.', Journal of Economic and Social Development, 3(2), pp. 51-58.

Barsky, R. B. and Kilian, L. (2002). "Do We Really Know that Oil Caused the Great Stagflation? A Monetary Alternative,". NBER Macroeconomics Annual 2001. 16(1): pp.137-197. 
Barsky, R. B. and kilian, L. (2004). Oil and the Macroeconomy Since the 1970s," Journal of Economic Perspectives. Journal of Economic Perspectives. 18(4): pp.115-134.

Barsky, R.B. and Kilian, L. (2001). "Do we really know that oil caused the great stagflation? A monetary alternative". Available from: https://econpapers.repec.org/paper/nbrnberwo/8389.htm [Accessed 9th November 2019].

Baumeister, C. and Kilian, L. (2016) 'Forty Years of Oil Price Fluctuations: Why the Price of Oil May Still Surprise Us', The Journal of Economic Perspectives, 30(1), pp. 139-160 doi: 10.1257/jep.30.1.139.

Bentley, Y. and Bentley, R. (2015) 'Explaining the price of oil 1971-2014: The need to use reliable data on oil discovery and to account for 'mid-point' peak', Energy Policy, 86, pp. 880-890. doi: 10.1016/j.enpol.2015.04.028.

Blanchard, O.J. and Riggi, M. (2013) 'Why are the 2000s SO Different from the 1970s? a Structural Interpretation of Changes in the Macroeconomic Effects of oil Prices', Journal of the European Economic Association, 11(5), pp. 1032-1052. doi: 10.1111/jeea.12029.

Blinder, A. S. and Rudd, J. B. (2008). The Supply Shock Explanation of the Great Stagflation Revisited. Available from: https://www.princeton.edu/ceps/workingpapers/176blinder.pdf [Accessed 4th June, 2020].

Bloomberg Business (2016a). Here's How Electric Cars Will Cause the Next Oil Crisis, by Tom Randall. Available from: https://www.bloomberg.com/features/2016-ev-oil-crisis/ [Accessed 5th May 2019].

Bowen, C.M. (2011) A historical analysis of crude oil prices. Available at: http://www.brighthub.com/money/investing/articles/121955.aspx(Accessed: 9 April 2019).

Bowler, T. (2015) Falling oil prices: Who are the winners and losers? Available at: http://www.bbc.co.uk/news/business-29643612 (Accessed: 18 January 2020).

Brown, S.P. (2006) 'Making Sense of High Oil Prices: A conversation with Stephen P A. Brown.', FRB Dallas Southern Economy, (4), pp. 8-9.

Campbell, C.J. (2012) 'The Oil Age in Perspective', Energy Exploration \& Exploitation, 31(2), pp. 149-165.

ChartsBin Statistics collector team (2014)Historical Crude Oil Prices, 1861 to present, ChartsBin.com. Available at: http://chartsbin.com/view/oau (Accessed: 2 December, 2019).

Cohen, D. (2009) 2009 - A Year We Will Live To Regret. Available at: http://www.resilience.org/stories/200912-17/2009-\%E2\%80\%94-year-we-will-live-regret (Accessed: 10 June 2020).

Cox, L. (2015) The Surprising Decline in US Petroleum Consumption. Available at: https://www.weforum.org/agenda/2015/07/the-surprising-decline-in-us-petroleumconsumption/ (Accessed: 20 July 2019).

Cremer, J. and Salehi-Isfahani, D. (1989) 'The rise and fall of oil prices: A competitive view.', Annales d'Economie et de Statistique, 15(16), pp. 427-454.

Daniel, W. (2016) World's Top Exports (WTEx): Crude Oil Exports by Country. Available at: http://www.worldstopexports.com/worlds-top-oil-exports-country/ (Accessed: 20 July 2020).

DeVore, M. R. (2009). A convenient framework: The Western European Union in the Persian Gulf, 1987-1988 and 1990-1991. European Security. 18(2): pp.227-243.

Dvir, E. and Rogoff, K. (2010). The Three Epochs of Oil. Available from: http://scholar.harvard.edu/files/rogoff/files/three_epochs_of_oil.pdf. [Accessed 15th January 2019].

Edwards, N. (2020) What Negative Oil Prices Mean To The Top Exporting Countries. Available at: https://www.forbes.com/sites/neiledwards/2020/04/21/what-negative-oil-prices-mean-to-the-topexporting-countries/?sh=fff2937d1642 (Accessed: 17th March 2021).

EIA (2015). The Annual Energy Outlook 2015 with Projections to 2040. Available from: https://www.hsdl.org/?abstract\&did=767364 [Accessed 5th May 2020].

Emami, K. and Adibpour, M. (2012). Oil income shocks and economic growth in Iran. Economic Modelling. 29(5): pp.1774-1779.

Fahey, M. (2015) Oil Prices and Budgets: The OPEC Countries Most at Risk. Available at: http://www.cnbc.com/2015/12/03/oil-prices-and-budgetsthe-opec-countries-most-at-risk.html (Accessed: 20 January, 2021).

Filis, G., Degiannakis, S. and Floros, C. (2011). Dynamic correlation between the stock market and oil prices: The case of oil-importing and oil-exporting countries. Available from: https://core.ac.uk/download/pdf/9630160.pdf [Accessed 27th June, 2020].

Flavin, C. (1985) World Oil: Coping with the Dangers of Success. Available at: http://files.eric.ed.gov/fulltext/ED260889.pdf (Accessed: 12 May 2020).

'Game of oil and the global economy', (2016) The Assam Tribune, Available at: https://static1.squarespace.com/static/5b4f78e18f5130a8218ee9bb/t/5ce543a83200ac00011 ea50b/15585289 59078/Assam+Tribune+Review+Nightmarch.pdf (Accessed: 12th November 2020). 
Gately, D. (1984) 'A Ten-Year Retrospective: OPEC and the World Oil Market', Journal of Economic Literature, 22(3), pp. 1100.

Goldenberg, S. (2016) The Guardian: US and Canada Promise to Lead World to Low-Carbon Economy. Available at: https://www.theguardian.com/environment/2016/mar/10/us-canada-promise-leadworld-low-carbon-economy-obama-trudeau (Accessed: 15th December 2020).

Goswami, A. (2012) World Oil Market: Prices and Crisis. Available at: http://www.e-ir.info/2012/12/28/worldoil-market-prices-and-crises/ (Accessed: 10 April 2020).

Graefe, L. (2013) Oil $\quad$ Shock $\quad$ of $1978 \quad$ - $\quad$ 1979. Available at: http://www.federalreservehistory.org/Events/DetailView/40 (Accessed: 2 May 2020).

Griffin, J.M. (1985) 'OPEC Behavior: A Test of Alternative Hypotheses', The American Economic Review, 75(5), pp. 954-963.

Hamilton, J.D. (1983) 'Oil and the Macroeconomy since World War II', Journal of Political Economy, 91(2), pp. 228-248. doi: 10.1086/261140.

Hamilton, J.D. (1985) 'Historical Causes of Post War Oil Shocks and Recessions.', Energy Journal, 6(1), pp. $97-$ 116.

Hamilton, J.D. (2003) 'What is an Oil Shock?', Journal of econometrics, 113(2), pp. 363-398.

Hamilton, J.D. (2005) 'Oil and the Macroeconomy', The New Palgrave Dictionary of Economics Palgrave Macmillan, London. Available online at http://www.dictionaryofeconomics.com/dictionary.JiménezRodríguez, Rebeca and Marcelo Sánchez, , pp. 201-228.

Hamilton, J.D. (2008) Understanding Crude Oil Prices. Available at: http://nowandfutures.com/large/UNDERSTANDING CRUDE OIL PRICES speculators w14492(15 precent_effect)(StlFed).pdf (Accessed: 15th January 2021)..

Hamilton, J.D. (2009a) "'Understanding Crude Oil Prices". The Energy Journal, International Association for Energy Economics.', The Energy Journal, 30(2), pp. 179-206. doi: 10.5547/ISSN0195-6574-EJ-Vol30No2-9.

Hamilton, J.D. (2009b) Causes and Consequences of the Oil Shock of 2007-08. Available at: http://www.brookings.edu/about/projects/bpea/editions/ /media/Projects/BPEA/Spring\%202009/2009a bpea hamilton.PDF (Accessed: 15 January 2021).

Hamilton, J.D. (2011) Historical

Oil

Shocks. Available at: http://econweb.ucsd.edu/ jhamilton/oil_history.pdf (Accessed: 9 January 2021).

Hammes, D. and Wills, D. (2005) Black Gold: The end of Bretton woods and the oil price shocks of the 1970s. Available at: http://faculty.washington.edu/dtwills/resources/Black-Gold-IR.pdf(Accessed: 21 April 2020).

Harris, J.M. and Roach, B. (2017) Environmental and Natural Resource Economics: A Contemporary Approach - Energy, the Great Transition. Available at: http://www.ase.tufts.edu/gdae/Pubs/te/ENRE/4/Ch11_Energy_4E.pdf (Accessed: 11th December 2020).

Haryono, R. (2012). Precautionary Demand for Oil and Political Instability in the Middle East and North Africa. Available from: https://www.business.unsw.edu.au/About-Site/Schools-Site/EconomicsSite/Documents/HARYONO\%20(2012)\%20Precautionary\%20Demand\%20for\%20Oil.pdf [Accessed 9th June2020].

Hejny, S. and Nielsen, J. (2003) Past, Present, and Future of Petroleum. Available at: http://web.stanford.edu/class/e297a/Past,\%20Present \%20and\%20Future\%20of\%20Petroleum.pdf (Acces sed: 21 April 2020).

Hejny, S. and Nielsen, J. (2003) Past, Present, and Future of Petroleum. Available at: http://web.stanford.edu/class/e297a/Past,\%20Present\%20and\%20Future\%20of\%20Petroleum.pdf (Acces sed: 21 April 2020).

Hinckley, E. (2015a) Energy Post: Saudi Arabia Sees End of Oil Age on the Horizon. Available at: http://cleantechnica.com/2015/02/06/saudi-arabia-sees-end-oil-age-horizon/ (Accessed: 20 March 2020).

Hinckley, E. (2015b) Energy Trends: Everything Has Changed - Oil And End of OPEC. Available at: http://www.energytrendsinsider.com/2015/01/20/everything-has-changed-oil-and-the-end-ofopec/\#more-17430 (Accessed: 3rd March 2020).

Holden, S. (2013) 'Avoiding the Resource Curse: The Case of Norway', Energy Policy, 1(63), pp. 870-876. doi: DOI: 10.1016/j.enpol.2013.09.010.

Hough, D. and Barton, C. (2016) Oil Price Outlook and Price Trends. House of Commons Library. Available at: file://C:/Users/1404750/Downloads/SN02106\%20(4).pdf (Accessed: 11 June 2020).

Husain, A.M. et al., (2015) Global implications of lower oil prices: International Monetary Fund. Available at: https://www.imf.org/external/pubs/ft/sdn/2015/sdn1515.pdf (Accessed: 15th March 2020).

IEA (2020) Global Energy Review 2020: The impacts of the Covid-19 crisis on global energy demand and CO2 emissions. Available at: https://webstore.iea.org/download/direct/2995 (Accessed: 17th March 2021). 
IEA, W.D. (2016) What drives crude oil prices? An analysis of 7 factors that influence oil markets, with chart data updated monthly and quarterly. Available at: http://web.macam.ac.il/ arnon/IntME/oil/Crude\%20Oil\%20Prices.htm (Accessed: 9 April 2020).

Illinois Oil \& Gas Association (IOGA) (2015) History of Crude Oil Prices. Available at: http://www.ioga.com/history-of-crude-oil-prices (Accessed: 2 May 2020).

'IMF' (2015) Norway: selected issues; IMF country reports 15/250. Available at: https://www.imf.org/external/pubs/ft/scr/2015/cr15250.pdf(Accessed: 6 March 2020).

International Institute for Sustainable Development, (IISD) (2014) The Impact of Fossil Fuel Subsidies on Renewable Energy Generation. Available at: https://www.iisd.org/gsi/impact-fossil-fuel-subsidiesrenewable-energy (Accessed: 12th December 2020).

Jiménez-Rodríguez*, R. and Sánchez, M. (2005) 'Oil price shocks and real GDP growth: empirical evidence for some OECD countries', Applied Economics, 37(2), pp. 201-228.

Kaminski, F. (2010) Review: Twilight in the Desert by Matthew Simmons. Available at: http://www.resilience.org/stories/2010-12-15/review-twilight-desert-matt-simmons (Accessed: 09 June 2020).

Kilian, L. (2008a). Exogenous oil supply shocks: how big are they and how much do they matter for the US economy? Review of Economics and Statistics. 90(1): pp.216-240.

Kilian, L. (2008b). The economic effects of energy price shocks. Journal of Economic Literature. 46(1): pp.871909.

Kilian, L. (2009). Oil Price Volatility: Origins and Effects. doi:10.30875/9b9f6bc8-en. Available from: https://www.econstor.eu/bitstream/10419/57602/1/639727123.pdf [Accessed 26th July 2019].

Kilian, L. (2015) Why did the price of oil fall after June, 2014? Available at: http://voxeu.org/article/causes2014-oil-price-decline (Accessed: 20 July 2019).

Kitous, A., Saveyn, B., Keramas, K., Vandyck, T., Santos, L. and Wojtowicz, K. (2016) Impact of Low Oil Prices on Oil Exporting Countries. Available at: http://publications.jrc.ec.europa.eu/repository/bitstream/JRC101562/jrc101562_impact\%20of\%20low\%2 0oil\%20prices\%2020160512.pdf (Accessed: 20 July 2020).

Klevnas, P., Stern, N. and Frejova, J. (2015) The New Climate Economy: Oil Prices and the new climate economy. Available at: https://www.seiinternational.org/mediamanager/documents/Publications/NEW/NCE-SEI-2015-Oil_prices.pdf (Accessed: 11 th December 2020).

Kolakowski, M. (2020) History of Oil Prices. Available at: https://www.investopedia.com/history-of-oil-prices4842834 (Accessed: 17th March 2021).

Kristopher, G. (2015). WTI and Brent Crude Oil Prices in 2015, Lowest since 2009. Available from: https://marketrealist.com/2016/01/wti-brent-crude-oil-prices-2015-lowest-since-2009/ (Accessed 7th March 2020)

Krugman, P. (2008) New York Times: Fuels on the Hill. Available at: http://www.nytimes.com/2008/06/27/opinion/27krugman.html?_r=0 (Accessed: 20 July 2020).

Li, R. (2010) 'The role of OPEC in the world oil market', International Journal of Business and Economics, Vol.9(No. 1), pp. 83-85.

Lin, C.C. (2011) 'Estimating supply and demand in the world oil market', The Journal of Energy and Development, 34(1), pp. 1-32.

Lorusso, M. and Pieroni, L. (2015) Causes and Consequences of Oil Price Shocks on the UK Economy. Centre for Energy Economics Research and Policy (CEERP). Available at: http://ceerp.hw.ac.uk/RePEc/hwc/wpaper/002.pdf (Accessed: 15 July 2019).

Macrotrends (2021) Crude Oil Prices - 70 Year Historical Chart. Available at: https://www.macrotrends.net/1369/crude-oil-price-history-chart (Accessed: 17th March 2021).

Macrotrends, (2019) Crude Oil Prices Today - Live Chart. Available at: https://www.macrotrends.net/2566/crude-oil-prices-today-live-chart (Accessed: 7th January 2019).

Mcmahon, T. (2015) Historical crude oil prices (Table): Oil prices 1946 - present. Available at: http://inflationdata.com/Inflation/Inflation_Rate/Historical_Oil_Prices_Table.asp (Accessed: 11 April 2019).

Mirhaydari, A. (2015) Four Reasons Oil Could Fall to $\$ 40$ a Barrel. Available at: http://www.thefiscaltimes.com/Opinion/2015/06/08/Four-Reasons-Oil-Could-Fall-40-Barrel (Accessed: 26 June 2020).

Moffat, C. (2008) The History of Oil Prices - Oil and Gasoline Economics: Oil Price History and Analysis. Available at: http://www.politics.lilithezine.com/History-of-Oil-Prices.html (Accessed: 10 April 2020).

Monaldi, F. (2015). The Impact of the Decline in Oil Prices on the Economics, Politics and Oil Industry of 
Venezuela.

from: https://energypolicy.columbia.edu/sites/default/files/Impact $\% 20$ of $\% 20$ the $\% 20$ Decline $\% 20$ in $\% 20$ Oil $\% 20$ Prices $\% 20$ on $\% 20$ Venezuela_September\%202015.pdf

(Accessed 9th June 2019).

Morale, A. (2010) Bloomberge: Fossil Fuel Subsidies are Twelve Times Renewables Support. Available at: https:/www.bloomberg.com/news/articles/2010-07-29/fossil-fuel-subsidies-are-12-times-support-forrenewables-study-shows (Accessed: 12th December 2020).

Morana, K. (2013). The oil price-macroeconomy relationship since the mid-1980s: A global perspective. The Energy Journal. 34(3): pp.153-189.

Mork, K.A. (1989) 'Oil and the Macroeconomy When Prices Go Up and Down: An Extension of Hamilton's Results', Journal of Political Economy, 97(3), pp. 740-744. doi: 10.1086/261625.

Motyka, M., et al., (2017) Deloitte: Using Renewable Energy to Drive Supply Chain Innovation. Available at: https://www2.deloitte.com/content/dam/Deloitte/us/Documents/manufacturing/us-manufacturingsupply-chain-of-the-future-renewable-energy.pdf (Accessed: 12th December 2020).

Nachtgal, D. and Rubbelke, D. (2013) The Green Paradox and Learning-by doing in the Renewable Energy Sector. Available at: file://C:/Users/1404750/Downloads/BC3WP201309.pdf (Accessed: 15th December 2020).

Nicholson, W. and Snyder, C. (2007) Microeconomic Theory: Basic Principles and Extensions. $10^{\text {th }}$ Ed. Thomson Higher Education. United States of America

Nzimande, N.P. and Msomis, S. (2016) Oil Price Shocks and Economic Activity: The Asymmetric Cointegration Approach in South Africa. Available at: http://saef.ukzn.ac.za/Libraries/Working_Paper/SAEF_Oil_Price_Shocks-NN_SM.sflb.ashx (Accessed: 16 July 2020).

Obstfeld, M., Milesi-Ferretti, G.M. and Arezki, R. (2016) Oil prices and the global economy: It's complicated. Available at: https://blog-imfdirect.imf.org/2016/03/24/oil-prices-and-the-global-economy-itscomplicated/ (Accessed: 09 January 2020).

OECD (2020) Oil Price Developments: Drivers, Economic Consequences and Policy Responses. Available at: oecd.org/economy/outlook/34080955.pdf (Accessed: 17th March 2021).

OECD/IEA (2015) Medium Term Oil Market Report. Available at: https://www.iea.org/Textbase/npsum/MTOMR2015sum.pdf (Accessed: 2nd January 2020).

OilPrice.com (2021) The No. 1 Source for Oil and Energy News. Available at: (Accessed: 17th March 2021).

OPEC (2013) Managing the price of crude oil - A case study of OPEC. Available at: http://www.spireenergy.com/wp-content/uploads/2013/11/OPEC-and-Crude-Oil-Prices.pdf (Accessed: 23 April 2020).

OPEC Annual Statistical Bulletin (2018) OPEC share of world crude oil reserves, 2017. Available at: https://www.opec.org/opec_web/en/data_graphs/330.htm (Accessed: 5th December 2020).

Ouliaris, S., Pagan, A. R. and Restrepo, J. (2018). Quantitative Macroeconomic Modeling with Structural Vector Autoregressions - $\quad$ An EViews Implementation. Available from: https://www.eviews.com/StructVAR/structvar.html [Accessed 13th April 2020].

Papandreou, A. and Ruzzenenti, F. (2015) Financialisation, Economy, Sociey and Sustaibable Development (FESSUD): On the Effects of Fossil Fuel Prices on the Transition Towards a Low Carbon Energy System. Available at: http://fessud.eu/wp-content/uploads/2015/03/Papandreou Ruzzeneti Effects-of-fossilfuel-prices-on-transition-to-low-carbon-energy-part-A-working-paper-89.v2.pdf(Accessed: 11 th December 2020).

Pindyck, R.S. (2001) 'Gains to Producers from the Cartelization of Exhaustible Resources', The review of economics and statistics, 60(2), pp. 238-251.

Qianqian, Z. (2011) 'The Impact of International Oil Price Fluctuation on China's Economy ', Energy Procedia, 5(2011), pp. 1360-1364.

Rahman, M. (2004) Oil and gas: The engine of the world economy. Available at: http://www.opec.org/opec web/en/900.htm (Accessed: 5th January 2017).

Rascouet, A. (2015) Bloomberg: Oil States Need Price Jump to Balance Budget - OPEC Reality Check. Available at: http://www.bloomberg.com/news/articles/2015-11-30/oil-states-need-price-jump-tobalance-budget-opec-reality-check (Accessed: 26 July 2016).

Roberts, L. (2018.) Why the Oil Price Bear Market Persists. Oil price.com. Available from: https://oilprice.com/Energy/Crude-Oil/Why-The-Oil-Price-Bear-Market-Persists.html [Accessed 19th December 2020].

Rogoff, K. (2016) World Economic Forum: What's behind the drop in oil prices? Available at: https://www.weforum.org/agenda/2016/03/what-s-behind-the-drop-in-oil-prices/ (Accessed: 18 June 2020).

Schall, L. (2009) Matthew Simmons: "Global Crude Oil Peaked in 2005". Available at: http://www.resilience.org/stories/2009-11-10/matthew-simmons-\%E2\%80\%9Cglobal-crude-oil-peaked- 
2005\%E2\%80\%9D-interview (Accessed: 08 June 2020).

Simmons, M.R. (2005) Twilight in the Desert: The Coming Saudi Oil Shock and the World Economy, Boboken, N.J.: John Wiley \& Sons. United States.

Singh, J. (2016) Law of Demand: Meaning, Reasons and Exceptions to the law of Demand (with Diagram). Available at: http://www.economicsdiscussion.net/essays/economics/law-of-demand-meaningreasons-and-exceptions-to-the-law-of-demand-with-diagram/916(Accessed: 17th January 2019).

Sinn, H.W. (2012) The Green Paradox: A Supply-Side Approach to Global Warming. Cambridge and Mass, MIT Press. Available at: https://mitpress.mit.edu/books/green-paradox (Accessed: 15th December 2019).

Stevens, P.P. (2009) 'Declining Oil Revenues in the GCC States: A Threat or an Opportunity?', Whitehall Papers, 51(1), pp. 118-133. doi: 10.1080/02681300009414861.

Sturm, M., Gurtner, F. and Alegre, J.G. (2009). 'Fiscal Policy Challenges in Oil-exporting Countries - A Review of Key Issues'. Available from: https://www.ecb.europa.eu/pub/pdf/scpops/ecbocp104.pdf?4b00f0923bf45[Accessed 9th September 2018].

Taghizadeh-Hesary, F. (2020) Economic impacts of the COVID-19 pandemic and oil price collapse. Available at: https://www.asiapathways-adbi.org/2020/05/economic-impacts-covid-19-pandemic-and-oil-pricecollapse/ (Accessed: 17th March 2021).

Taghizadeh-Hesary, F. and Yoshino, N. (2015) Macroeconomic Effects of Oil Price Fluctuations on Emerging and Developed Economies in a Model Incorporating Monetary Variables. Available at: https://www.econstor.eu/bitstream/10419/145394/1/838107419.pdf (Accessed: 7th January 2020).

The New York Times (2008) Bloomberge: Oil's Long Price Rise Quickly Undone. Available at: http://www.nytimes.com/imagepages/2008/12/16/business/16oil.graphic.html (Accessed: 15 June 2020).

Timilsina, G.R. (2014) 'Oil prices and the global economy: A general equilibrium analysis', Energy Economics, 49, pp. 669-675. doi: 10.1016/j.eneco.2015.03.005.

Timmons, D., Harris, J.M. and Roach, B. (2014) Global Development and Environment Institute: The Economics of Renewable Energy. Available at: http://www.ase.tufts.edu/gdae/education_materials/modules/RenewableEnergyEcon.pdf (Accessed: 11th December 2020). Economics

1946-2016. Available at: http://www.tradingeconomics.com/commodity/crude-oil (Accessed: 7 April 2020).

Wesley, P.A. (2010) OPEC. Available at: http://wps.aw.com/aw_carltonper_modernio_4/0,9313,1424964content,00.html (Accessed: 25 April 2020).

Williams, J. L. (2007).. History and Analysis of crude oil prices. Available from: https://msuweb.montclair.edu/ lebelp/PSC643IntPolEcon/CrudeOilPriceTrends.pdf [Accessed 9 April 2020].

Williams, J.L. (1999) OPEC post meeting Analysis: Oil price history and analysis. Available at: http://web.macam.ac.il/ arnon/Int-ME/oil/Crude\%200i1\%20Prices.htm (Accessed: 9 April 2020).

Williams, J.L. (2011) Oil price history and analysis. Available at: http://www.wtrg.com/prices.htm (Accessed: 31 March 2020).

Williamson, H.F., Anreano, R.L. and Menezes, C. (1966) The American Petroleum Industry: Output, Employment and Productivity in the United States after 1800. Available at: http://www.nber.org/chapters/c1572.pdf (Accessed: 10 April 2020).

World Energy Council (2016) World Energy Council: World Energy Resources. Available at: https://www.worldenergy.org/wp-content/uploads/2016/10/World-Energy-Resources-Full-report2016.10.03.pdf (Accessed: 11th December 2020).

Yanar, R. (2014) Effects of oil price plunge on the MENA economies. Available at: http://www.orsam.org.tr/files/Raporlar/rapor194/194eng.pdf(Accessed: 7th December 2020).

Yoshino, N. and Taghizadeh-Hesary, F. (2014) 'Economic impacts of oil price fluctuations in developed and emerging economies', IEEJ Energy Journal, 9(3), pp. 58-75. 